\title{
GACETAS Y RELACIONES DE SUCESOS (AÑOS 1700-1704) EN UN LEGAJO DE LA BIBLIOTECA DA UNIVERSIDADE DE SANTIAGO*
}

\author{
Por \\ CARLOS SANTOS FERNÁNDEZ
}

\section{RESUMEN}

Catálogo de quince relaciones de sucesos y nueve noticieros periódicos que se conservan, entre los restos de tres volúmenes de la Gaceta de Madrid del período 1700-1704, en la Biblioteca da Universidade de Santiago. Los veinticuatro impresos que describimos, fechados entre 1702 y 1704 , giran en torno al advenimiento de Felipe $\mathrm{V}$ al trono de España y a los sucesos militares y políticos, tanto nacionales como internacionales, que desembocarían en la Guerra de Sucesión española.

\section{PALABRAS CLAVE}

Literatura efímera, Relaciones de sucesos, Biblioteca da Universidade de Santiago, Felipe V, Guerra de Sucesión.

* Sirva la primera nota para expresar mi agradecimiento a la dirección y personal de la Biblioteca Xeral da Universidade de Santiago de Compostela por las facilidades dispensadas para la realización de este trabajo, gratitud que quiero particularizar en doña Aurora Bouza, por su eficacia y amabilidad.

«CUADERNOS DE ESTUDIOS GALLEGOS», Tomo XLIX, Fascículo 115, Santiago 2002. 


\begin{abstract}
Catalogue of fifteen accounts of events and nine news articles stored among the remains of three volumes of the Gaceta de Madrid from the period 1700-1704 and deposited at Santiago University Library. The twenty-four pieces of printed matter which we describe, dating from between 1702 and 1704, focus on accession of Philip V to the throne of Spain and on the national and international military and political events leading to the War of Spanish Succession.
\end{abstract}

\title{
KEYWORDS
}

Ephemeral literature, Relations of events, Library of the University of Santiago, Philip V, War of Succession.

Cuando, en el año 1999, enviamos a Cuadernos de Estudios Gallegos el trabajo titulado «Contribución al Catálogo de relaciones de sucesos en bibliotecas de la provincia de A Coruña» intuíamos que, al margen de quien pudiera ser su autor, ésta no sería la última aportación al Catálogo de Relacións de Sucesos (1500-1750) nas Bibliotecas da Provincia da Coruña iniciado por Nieves Pena Sueiro. Si en aquellas páginas de Cuadernos de Estudios Gallegos, que tan amablemente acogieron nuestra colaboración, apuntábamos la probabilidad de que fueran apareciendo nuevos ejemplares de relaciones que ampliaran el Catálogo de Pena Sueiro, éstas nos sirven para presentar una colección de impresos noticieros que hemos localizado, encuadernados entre ejemplares de la Gaceta de Madrid del período 1700-1704, en la Biblioteca Xeral da Universidade de Santiago de Compostela (= BUS).

\section{EL LEGAJO PUBLIC.DIARIA-48 (1700-1704) DE LA BUS}

El legajo Public.Diaria-48 (1700-1704) de la BUS contiene los maltratados restos de tres volúmenes de la Gaceta de Madrid del período 1700-1704 que, desgajados de sus cubiertas y mutilados, alguien recogió 
en un sencillo atado protegido, a modo de menguada cubierta, por el papel de un embalaje de libros enviados desde Argentina, manuscribiendo a bolígrafo en el lomo las fechas límites de los documentos que precariamente protegía: 1700-1704.

Una somera revisión revela que la unidad cronológica que apuntan las fechas manuscritas en el lomo se opone a la heterogeneidad tipológica de su contenido; intercalados entre los ejemplares de la Gaceta de Madrid aparecen noticiarios, opúsculos políticos, relaciones de sucesos y traslados de órdenes, vinculados por un nexo temático: la Guerra de Sucesión. La vertebración de esta colección de documentos en torno al conflicto provocado por el fallecimiento sin descendencia de Carlos II se pone de manifiesto en un hecho casual pero que parece premonitorio: el primer ejemplar de la Gaceta que se conserva en este legajo, fechado el 2 de noviembre de 1700 , refiere la agonía y el fallecimiento del último monarca español de la estirpe de los Austrias, suceso que dará lugar a un enfrentamiento -antes internacional que nacional-, que marcará la historia europea del Siglo de la Revolución, y cuyos vagidos se pueden percibir en los documentos que componen el legajo que nos ocupa.

Materialmente, el contenido del atado está formado por los restos de tres volúmenes de la Gaceta de Madrid (años 1700-1701, 1702 y 1704), entre cuyos números se intercalaron impresos y manuscritos. El contenido actual (abril de 2002) de cada uno de los volúmenes es el siguiente:

\section{A.- Años 1700-1701:}

El primer bloque de impresos está compuesto por 24 números de la Gaceta de Madrid, desde el no 44 de 1700 ( 2 de noviembre) hasta el $n^{\circ} 15$ de 1701 ( 12 de abril); esta serie, prácticamente correlativa (falta el número 13 de 1701, correspondiente al 29 de marzo), evidencia la pérdida del principio y el final del volumen, que estaría formado, al menos, por los 104 números correspondientes a dos años de esta publicación (además de un número indeterminado de impresos intercalados, cuya existencia podemos presuponer a la vista de los otros dos volúmenes).

De los años 1700-1701 se conservan los números que relacionamos a continuación ${ }^{1}$ :

\footnotetext{
${ }^{1}$ Indicamos el número $\mathrm{y}$, entre paréntesis, la fecha de publicación, que en todos los casos corresponde a un martes.
} 
- Año 1700. $G d M \mathrm{n}^{\circ} 44$ (2.noviembre) $\| G d M \mathrm{n}^{\circ} 45$ (9.noviembre) $\|$ $G d M \mathrm{n}^{\circ} 46$ (16.noviembre) $\| G d M \mathrm{n}^{\circ} 47$ (23.noviembre) $\| G d M \mathrm{n}^{\circ}$ 48 (30.noviembre) $\| G d M \mathrm{n}^{\circ} 49$ (7.diciembre) $\| G d M \mathrm{n}^{\circ} 50$ (14.diciembre) $\| G d M \mathrm{n}^{\circ} 51$ (21.diciembre) $\| G d M \mathrm{n}^{\circ} 52$ (28.diciembre).

- Año 1701. $G d M \mathrm{n}^{\circ} 1$ (4.enero) $\| G d M \mathrm{n}^{\circ} 2$ (11.enero) $\| G d M \mathrm{n}^{\circ} 3$ (18.enero) $\| G d M \mathrm{n}^{\circ} 4$ (25.enero) $\| G d M \mathrm{n}^{\circ} 5$ (1.febrero) $\| G d M \mathrm{n}^{\circ}$ 6 (8.febrero) $\| G d M \mathrm{n}^{\circ} 7$ (15.febrero) $\| G d M \mathrm{n}^{\circ} 8$ (22.febrero) $\|$ $G d M \mathrm{n}^{\circ} 9$ (1.marzo) $\| G d M \mathrm{n}^{\circ} 10$ (8.marzo) $\| G d M \mathrm{n}^{\circ} 11$ (15.marzo) $\| G d M \mathrm{n}^{\circ} 12$ (22.marzo) $\| G d M \mathrm{n}^{\circ} 14$ (25.abril) $\| G d M \mathrm{n}^{\circ} 15$ (12.abril).

\section{B.- Año 1702:}

Conserva íntegra la colección de Gacetas de 1702 y, presumiblemente, todos los impresos que se encuadernaron interpolados, además de las dos hojas de guarda posteriores. Los cantos tintados en rojo ponen de manifiesto su carácter de volumen independiente respecto al resto de documentos del legajo.

La serie que se conserva, incluyendo las interpolaciones, es la siguiente:

- Año 1702. $G d M \mathrm{n}^{\circ} 1$ (3.enero) $\| G d M \mathrm{n}^{\circ} 2$ (10.enero) $\| G d M \mathrm{n}^{\circ} 3$ (17.enero) || Noticias extraordinarias ... 22 de enero de 1702 [A] \| $G d M \mathrm{n}^{\circ} 4$ (24.enero) $\| G d M \mathrm{n}^{\circ} 5$ (31.enero) $\| G d M \mathrm{n}^{\circ} 6$ (7.febrero) $\| G d M \mathrm{n}^{\circ} 7$ (14.febrero) $\| G d M \mathrm{n}^{\circ} 8$ (21.febrero) $\| G d M \mathrm{n}^{\circ} 9$ (28.febrero) $\| G d M \mathrm{n}^{\circ} 10$ (7.marzo) \| Noticia particular del sucesso de Cremona [1] \| $G d M \mathrm{n}^{\circ} 11$ (14.marzo) \| $G d M \mathrm{n}^{\circ} 12$ (21.marzo) \| Relación de las ceremonias [2] $\| G d M \mathrm{n}^{\circ} 13$ (28.marzo) $\| G d M \mathrm{n}^{\circ}$ 14 (4.abril) || Noticias extraordinarias ... 11 de abril de 1702 [B] || $G d M \mathrm{n}^{\circ} 15$ (11.abril) $\| G d M \mathrm{n}^{\circ} 16$ (18.abril) $\| G d M \mathrm{n}^{\circ} 17$ (25.abril) || Copia de carta ... escrivió Monsieur de Torsi [3] || Noticias extraordinarias ... 29 de abril de 1702 [C] \| GdM n 18 (2.mayo) \| Noticias extraordinarias y diario del feliz viage ... [4] \|GdM $\mathrm{n}^{\circ} 19$ (9.mayo) $\| G d M \mathrm{n}^{\circ} 20$ (16.mayo) $\| G d M \mathrm{n}^{\circ} 21$ (23.mayo) $\| G d M \mathrm{n}^{\circ}$ 22 (30.mayo) $\| G d M \mathrm{n}^{\circ} 23$ (6.junio) $\| G d M \mathrm{n}^{\circ} 24$ (13.junio) $\|$ Noticias extraordinarias ... 13 de junio de 1702 [D] $\| G d M \mathrm{n}^{\circ} 25$ (20.junio) || Puntual y sincera relación ... [5] \|GdM n 26 (27.junio) \| $G d M \mathrm{n}^{\mathrm{o}} 27$ (4.julio) \| Relación verdadera y puntual ... [6] $\| G d M \mathrm{n}^{\circ}$ 28 (11.julio) \| $G d M \mathrm{n}^{\circ} 29$ (18.julio) \| Noticias extraordinarias ... 18 de julio de 1702 [E] $\| G d M \mathrm{n}^{\circ} 30$ (25.julio) $\| G d M \mathrm{n}^{\circ} 31$ (1.agos- 
to) $\| G d M \mathrm{n}^{\circ} 32$ (8.agosto) $\|$ Feliz empresa y victorioso reencuentro ... [7] $\| G d M \mathrm{n}^{\circ} 33$ (15.agosto) $\| G d M \mathrm{n}^{\circ} 34$ (22.agosto) $\| G d M \mathrm{n}^{\circ}$ 35 (29.agosto) $\| G d M \mathrm{n}^{\circ} 36$ (5.septiembre) $\| G d M \mathrm{n}^{\circ} 37$ (12.septiembre) || Noticias extraordinarias ... 12 de septiembre de 1702 [F] $\| G d M \mathrm{n}^{\circ} 38$ (19.septiembre) \| $G d M \mathrm{n}^{\circ} 39$ (26.septiembre) \| $G d M \mathrm{n}^{\circ} 40$ (3.octubre) $\| G d M \mathrm{n}^{\circ} 41$ (10.octubre) $\| G d M \mathrm{n}^{\circ} 42$ (17.octubre) || Copia de carta escrita de Munich ... [8] || Noticias extraordinarias ... 17 de octubre de 1702 [G] || Opúsculo político: La verdad sin arte ... $\| G d M \mathrm{n}^{\circ} 43$ (24.octubre) $\|$ Breve relación de la victoria ... [9] $\| G d M \mathrm{n}^{\circ} 45$ (7.noviembre) $\| G d M \mathrm{n}^{\circ} 44$ (31.octubre) $)^{2} \| G d M$ n $^{\circ} 46$ (14.noviembre) $\| G d M$ n $^{\circ} 47$ (21.noviembre) \| $G d M \mathrm{n}^{\circ} 48$ (28.noviembre) \| Noticias singulares y extraordinarias ... por el mes de noviembre de $1702[\mathrm{H}] \| G d M \mathrm{n}^{\circ} 49$ (5.diciembre) $\| G d M \mathrm{n}^{\circ} 50$ (12.diciembre) $\| G d M \mathrm{n}^{\circ} 51$ (19.diciembre) $\| G d M \mathrm{n}^{\circ}$ 52 (26.diciembre) || Clara demonstración de las operaciones ... [10].

\section{C.- Año 1704:}

Desgajada en varios cuadernillos y parcialmente mutilada, está formada por 33 de las 59 Gacetas publicadas durante el año 1704 (faltan las correspondientes a enero, mayo, julio y agosto). Aunque el día de publicación de la Gaceta era el martes, hay un ejemplar $\left(n^{\circ} 27\right)$ «Del Sábado 14 de Junio de 1704» intercalado entre los números 26 (martes, 10 de junio) y 28 (martes, 17 de junio); éste y otros extraordinarios semejantes explicarían los 59 números (en lugar de 52) publicados en el año 1704.

La serie que se conserva es la siguiente:

- Año 1704. $G d M \mathrm{n}^{\circ} 7$ (12.febrero) $\| G d M \mathrm{n}^{\circ} 8$ (19.febrero) $\| G d M$ $\mathrm{n}^{\circ} 9$ (26.febrero) $\| G d M \mathrm{n}^{\circ} 10$ (4.marzo) \| Manuscrito: Decreto que expidió Su Magestad ... antes de salir de la Corte $\| G d M \mathrm{n}^{\circ} 11$ (11.marzo) $\| G d M \mathrm{n}^{\circ} 12$ (18.marzo) $\| G d M \mathrm{n}^{\circ} 13$ (25.marzo) $\| G d M$ $\mathrm{n}^{\circ} 14$ (1.abril) || Copia de la carta de el Rey Christianíssimo [11] || GdM $\mathrm{n}^{\circ} 15$ (8.abril) \| Noticias singulares y ordinarias ... 12 de abril de 1704 [B] || || GdM n 16 (15.abril) \| GdM n 17 (22.abril) \|

${ }^{2}$ Evidentemente se trata de un error de encuadernación, anteponiéndose el número 45 al 44.

«CUADERNOS DE ESTUDIOS GALLEGOS», Tomo XLIX, Fascículo 115, Santiago 2002. 
Copia de carta del almirante ... [12] $\| G d M \mathrm{n}^{\circ} 18$ (29.abril) $\| G d M$

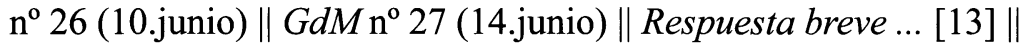
$G d M \mathrm{n}^{\circ} 28$ (17.junio) || Manuscrito: Horden de las nuebas compañías ... en junio de $1704 \| G d M \mathrm{n}^{\circ} 42$ (2.septiembre) || Relación que el sereníssimo ... [14] \|GdM no 43 (9.septiembre) $\| G d M \mathrm{n}^{\circ} 44$ (16.septiembre) || $G d M \mathrm{n}^{\circ} 45$ (23.septiembre) || Pronóstico sacado de los reyes de Portugal ... [15] \| GdM n 46 (30.septiembre) \| $G d M \mathrm{n}^{\circ} 47$ (7.octubre) $\| G d M \mathrm{n}^{\circ} 48$ (14.octubre) $\| G d M \mathrm{n}^{\circ} 49$ (21.octubre) $\| G d M \mathrm{n}^{\circ} 50$ (28.octubre) $\| G d M \mathrm{n}^{\circ} 51$ (4.noviembre) $\| G d M$ $\mathrm{n}^{\circ} 52$ (11.noviembre) $\| G d M \mathrm{n}^{\circ} 53$ (18.noviembre) $\| G d M \mathrm{n}^{\circ} 54$ (25.noviembre) $\| G d M \mathrm{n}^{\circ} 55$ (2.diciembre) $\| G d M \mathrm{n}^{\circ} 56$ (9.noviembre) $\| G d M \mathrm{n}^{\circ} 57$ (16.noviembre) $\| G d M \mathrm{n}^{\circ} 58$ (23.noviembre) $\|$ $G d M \mathrm{n}^{\circ} 59$ (30.noviembre).

\section{TIPOLOGÍA DOCUMENTAL}

Los ejemplares de la Gaceta de Madrid del período 1700-1704 constituyen el eje vertebral de esta colección que, a primera vista y dado su estado de conservación, semeja el vestigio de un naufragio librario. La homogeneidad de sus encuadernaciones anuales o bianuales sólo se ve interrumpida por la presencia de otros documentos, impresos o manuscritos, que se intercalaron entre las Gacetas en el momento de su publicación, ofreciéndonos la imagen de un cuidadoso coleccionista de periódicos y folletos que utiliza, como criterio de ordenación de los ejemplares, el orden de recepción. La (relativa) diversidad tipológica de los documentos del legajo permite establecer la siguiente clasificación:

\section{A.- Un semanario: Gaceta de Madrid}

A comienzos del siglo XVIII, la Gaceta de Madrid tenía un pasado cuarentón marcado por la irregularidad. Desde su aparición en 1661, auspiciada por D.Juan José de Austria y bajo la dirección de D. Francisco Fabro Bremundan e inspirada por las gacetas que surtían los mercados de París, Venecia, Roma, Amberes y otras capitales europeas, la historia de la Gaceta había experimentado altibajos e incluso la experiencia de una desaparición temporal como consecuencia de una Orden del Consejo de Castilla, dictada el 8 de abril de 1680, por la que se prohibía la impresión 
y circulación de gacetas. Reapareció en 1683, pero aún tendrían que transcurrir dos exangües sexenios hasta que, en 1696, don Juan de Goyeneche adquirió el Privilegio de impresión de gacetas que poseía el Hospital General de Madrid e impulsó su explotación comercial. En 1697 consolidó su encabezamiento como Gaceta de Madrid ${ }^{\beta}$ y adquirió una regularidad que hasta entonces había fluctuado tanto como el éxito comercial: veía la luz todos los martes en la librería madrileña de Antonio Bizarrón y constaba de dos hojas en cuarto, con paginación y signatura tipográfica correlativa para todo el año, los correspondientes reclamos y, si el espacio lo permitía, el colofón o un reclamo publicitario al final de cada ejemplar. Precisamente esos pies de página final nos desvelan dos aspectos que consideramos interesante señalar:

- Como colofón aparece esta leyenda: «Con Privilegio: Madrid. Por Antonio Bizarrón». El nombre de Antonio Bizarrón, además de en las Gacetas, aparece frecuentemente en los colofones de noticieros y relaciones de sucesos de los primeros años del siglo XVIII, y sin duda fue impresor además de librero y editor. Aunque se omite su nombre en el repertorio de impresores de la Gaceta [Centenario.GdM: 15], Delgado Casado señala que «es posible que tuviera imprenta activa en el siglo XVIII, pues está mencionado por Cruickshank como utilizador de tipos de Pedro Disses desde el año 1700 hasta 1707» [Delgado, Diccionario n ${ }^{\circ}$ 79]; también Gutiérrez del Caño [Gutiérrez, Ensayo: 83] y $\mathrm{M}^{\mathrm{a}}$ Pilar Cuesta [Cuesta, Romances, $\mathrm{n}^{\circ}$ 4] citan a Antonio Bizarrón como impresor madrileño durante el período 1701-1710.

- En algunos números de la Gaceta, el espacio habitualmente destinado al colofón se utiliza para otro tipo de mensaje que, en perjuicio de la constatación del Privilegio y del nombre del impresor, anticipa el recurso a la inserción de anuncios como vía de financiación, sistema que se consolidaría en la prensa decimonónica hasta desembocar en los actuales anuncios a dos planas completas que lastran (por el aumento de papel y por la

\footnotetext{
${ }^{3}$ La cabecera, presidida por un cristus, consignaba el número de orden anual, el título y la fecha de publicación. P. ej: «Num. <cristus> 173 / Gaceta de Madrid / Del Martes 2 de Noviembre de 1700».
} 
mengua de información) y financian en buena medida la prensa escrita de nuestros tiempos. El vaciado sistemático de la publicidad que la Gaceta de Madrid insertaba en algunos de sus números podría aportar nuevos datos sobre títulos, autores, fechas de publicación, editores o precios a la historia de la imprenta, la lectura y la edición en la España de comienzos del siglo XVIII; nosotros nos limitaremos a recoger los anuncios localizados en el manojo de Gacetas que manejamos, y a tratar de identificar la obra a la que hacen referencia:

1. «Hallarase en la mesma casa el Testamento del Rey nuestro Señor (que está en Gloria), o en la imprenta de Juan García Infançón, en la calle de Calatraba» en $G d M n^{\circ} 46$ (16 de noviembre de 1700). Se refiere a: Copia del testamento cerrado que en 2 de octubre de mil y setecientos, y del codicilio que ... hizo la Magestad del Señor Rey D.Carlos II, impreso en Madrid, en casa de Juan García Infanzón, en 1700 (4º, 27 pp. + 2 hs.) [Bustamante, CBU-XVIII n $\mathrm{n}^{\mathrm{0}} 76$ ].

2. «Donde estas relaciones se hallará la primera del viaje del Rey nuestro Señor» en $G d M n^{0} 51$ (21 de diciembre de 1700). Se trata de la Primera relación extraordinaria de la salida del Rey nuestro Señor Don Felipe Quinto, de Versalles para estos sus Reynos, y breves noticias de su Real Persona ... Publicada martes 21 de diziembre de 1700, edición de Madrid, por Antonio Bizarrón, $1700,4^{\circ}, 2$ hs. [Pena, RS.Coruña $\mathrm{n}^{\circ}$ 228]. Otra edición de esta relación se imprimió en Valladolid, por Antonio Figueroa, en 1700 $\left(4^{\circ}, 2\right.$ hs.) [Palau, $\left.M L H \mathrm{n}^{\circ} 259035\right]$.

3. «Adonde estas Relaciones se hallará el Arbol Genealógico del Rey nuestro Señor Felipe V» en $G d M n^{0} 52$ (28 de diciembre de 1700). Posiblemente este anuncio se refiera a la edición, carente de datos tipográficos, de Arbol genealógico y chronológico de la successión de la Monarquía de España, desde los señores reyes don Fernando y doña Isabel, hasta el señor Felipe Quinto que oy felizmente reyna, firmado por Félix Falco de Belaochaga $\left[C C P B \mathrm{n}^{\circ} 139946\right]$. Una edición posterior de la misma obra se imprimió en Valencia, en 1704 [Aguilar Piñal, BAE-3 $\mathrm{n}^{\circ}$ 1812].

4. «Donde estas relaciones se hallará el Gran Piscator de Sarrabal de Milán» en $G d M n^{\circ} 2$ (11 de enero de 1701). Thomas de Santo 
Agustini, el Piscatore de Sarrabal de Milán, fue un célebre autor de lunarios del siglo XVII, pero su seudónimo siguió utilizándose muchos años después de su muerte ${ }^{4}$. No hemos podido localizar la edición del Gran Piscatore de Sarrabal de Milán correspondiente al año 1701, aunque suponemos que no sería muy diferente de la de 1700 ( $8^{\circ}, 4$ hs. +62 pp.), impresa en Madrid por los Herederos de Antonio Román [Hurtado, Pronósticos: 59 n.22]. En 1708, Antonio Bizarrón imprimía en Madrid el Almanak universal sobre el año bisiesto de 1708, del Gran Piscator de Sarrabal de Milán, en $16^{\circ} \mathrm{y}$ compuesto por VIII+68 pp. [BNF $\mathrm{n}^{\circ} 30108655$ ].

5. «Adonde estas relaciones se hallará la llegada del Rey nuestro Señor a España» en $G d M n^{\circ} 5$ (1 de febrero de 1701). Se refiere a la Relación particular en que se da noticia de la entrada del Rey nuestro Señor en Bayona, de sus fiestas y recibimiento, y de la que hizo en Irún, primer pueblo de España. Publicada jueves 27 de enero de 1701, edición de Madrid, por Antonio Bizarrón, 1701, $4^{\circ}, 6$ pp. [Pena, RS.Coruña $\mathrm{n}^{\circ} 228$ ]. Otra edición de la misma relación se imprimió en Sevilla, por Francisco de Garay, en 1701 (4 $\left.4^{\circ}, 2 \mathrm{hs)} \mathrm{[Palau,} M L H \mathrm{n}^{\circ} 259038\right]$.

6. «En toda esta semana saldrá el célebre Pronóstico del Piscator de Sarrabal» en $G d M \mathbf{n}^{\circ} 2$ (10 de enero de 1702). Vid. $\mathrm{n}^{\circ} 4$.

7. «Donde estas relaciones se hallará el Gran Piscator de Sarrabal de Milán» en $G d M n^{\circ} 3$ (17 de enero de 1702). Vid. n ${ }^{\circ} 4$.

8. «Donde estas relaciones se hallará un libro nuevo intitulado Compendio anual de todos los sucessos principales acaecidos en la Europa el año passado de 1701» en $G d M$ n $^{\circ} 17$ (25 de abril de 1702). Corresponde al primer volumen del Compendio annual de los sucessos principales de la Europa, desde la muerte del Señor Don Carlos II, que de Dios goza, hasta el fin del año de 1701, compuesto por el presbítero Juan de la Cruz e impreso en Madrid, por Juan García Infanzón, en 1702 [Pena, RS.Coruña $\mathrm{n}^{\circ}$ 267]. La obra completa consta de cinco volúmenes (Madrid, Juan García Infanzón, 1702-1706) [Aguilar Piñal, $B A E-2 \mathrm{n}^{\circ} 4509$ ].

${ }^{4}$ Aún en 1768 se utilizaba el seudónimo Piscatore de Sarrabal de Milán [Aguilar Piñal, Prensa $\mathrm{n}^{\circ}$ 685] como medio de asegurar las ventas de los pronósticos. 
9. «Adonde estas relaciones se hallará un libro nuevo intitulado Synopsis de la historia de España, tomo segundo, por Don Juan de Ferreras, cura de San Andrés» en $G d M n^{\circ} 28$ (11 de julio de 1702). Se trata de la Synopsis Histórica Chronológica de España o Historia de España reducida a compendio ... parte segunda: comprende los sucessos de los quatro primeros siglos christianos, escrita por el clérigo e historiador bañezano Juan de Ferreras, en edición de Madrid impresa por Francisco de Villadiego a costa de Diego Lucas Ximénez en 1702, en $4^{\circ}$. [CCPB $\left.\mathrm{n}^{\circ} 140130\right]$.

10. «Adonde estas relaciones se hallarán las Ordenanzas militares para la formación de las milicias del Reyno» en $G d M n^{0} 8$ (19 de febrero de 1704). Se trata de las Ordenanzas militares para la formación de las milicias de el Reyno, impresas en Madrid, por Antonio Bizarrón, en 1704 ( $4^{\circ}, 8$ hs.) [CCPB n $\mathrm{n}^{\circ}$ 323097].

11. «Donde esas relaciones se hallará el Compendio annual de los sucessos de la Europa del año de 1703» en $G d M n^{\circ} 17$ (22 de abril de 1704). Vid. $\mathrm{n}^{\circ} 8$.

12. «Donde esas relaciones se hallará el Nuevo Mapa del Reyno de Portugal, con la Discrepción Geográfica de las Plazas» en $G d M n^{0} 27$ (14 de junio de 1704). No hemos podido localizar el Mapa de Portugal al que alude este anuncio, aunque sí su complemento $^{5}$, la Descripción geográfica histórica de el Reyno de Portugal, aumentada y corregida en esta segunda impressión, impresa en Madrid por Antonio Bizarrón $\left(4^{\circ}, 15 \mathrm{pp}\right.$.), en la que se explica: «Deseando dar más gustosa y cabal inteligencia al mapa de el Reyno de Portugal, se ha hecho la sumaria descripción de sus principales provincias, y en ellas las ciudades y villas fuertes que les pertenece, logrando el interés de servir a la curiosidad» (p.15).

13. «Donde estas relaciones se hallará el libro nuevo Commentaria in Scripturae Tautologicas. Su autor, el padre maestro Fr.Manuel de Villarroel, del Orden de San Benito» en $G d M \mathbf{n}^{\circ}$ 52 (11 de noviembre de 1704). Corresponde al volumen primero de In sacras tautologias, cum illustrationibus panegyricis,

${ }^{5}$ El ejemplar que hemos manejado (BUS: RSE.Misc.XXII-10) fue catalogado por Bustamante [CBU-XVIII $\left.\mathrm{n}^{\circ} 11909\right]$. 
anagogicis, tropologicis et politicis comentariorum literarium, del benedictino Fr.Manuel de Villarroel, edición de 1704, impresa en Madrid, in-folio, por Manuel Ruiz de Murga. La obra completa, en ocho volúmenes, se publicó entre 1704 y 1729.

14. «Donde estas relaciones se hallarán los Concilios del señor cardenal Aguirre, impressos en Roma en quatro tomos de a folio» en $G d M n^{0} 57$ (16 de diciembre de 1704). El anuncio hace referencia a la obra del cardenal José Sanz de Aguirre: Collectio maxima conciliorum omnium Hispaniae et Novi Orbis, impresa en Roma en 1694 por Joannes Jacobus Komarek, en cuatro volúmenes [Palau, $M L H \mathrm{n}^{\circ} 284301$ ].

15. «Donde estas noticias se hallará un libro intitulado: Retrato del verdadero sacerdote y Manual de sus obligaciones, compuesto por el padre Fr.Félix de Alamín, predicador apostólico capuchino» en Noticias singulares y ordinarias del estado presente de la Europa del 12 de abril de 1704. Corresponde al Retrato del verdadero sacerdote, y manual de sus obligaciones, escrito por el capuchino Fr.Félix de Alamín, en edición de Madrid, por Juan García Infanzón, 1704, in-4 $4^{\circ}$. [CCPB $\mathrm{n}^{\circ} 61163$.

Don Juan de Goyeneche fue director de la Gaceta en los primeros años del siglo XVIII, en los que, como señala Margarita Torrioni [Crónica: 18], servía como redactor Juan de las Hebas asistido por José Antonio de Avellaneda y, en la traducción de noticias, Juan Isidro Fajardo. El interés informativo de la Gaceta en los años iniciales del Siglo de las Luces se centraba en la información política o parapolítica inherente a la sucesión de Carlos II (información que los avatares de la Historia pronto transformarían en bélico-política), aunque sin desdeñar noticias de otros asuntos: necrológicas ${ }^{6}$, sociedad ${ }^{7}$, actos públicos ${ }^{8}$, avances

${ }^{6}$ «Murió el Sr.D.Pedro de Lepe, obispo de Calahorra...» [GdM, 14 de diciembre de 1700].

${ }^{7}$ «Ayer salió con gran lucimiento el señor Duque de Alburquerque para embarcarse en La Coruña a su Virreynato de la Nueva España» [ $G d M, 16$ de mayo de 1702].

${ }^{8}$ «El domingo, dos de enero, se hizo en el Convento de Santo Domingo [de Madrid] el Real Auto de Fe, en que salieron seis reos» [ $G d M, 4$ de enero de 1701]. Acerca de las celebraciones festivas y su reflejo en la Gaceta resulta fundamental el libro de Margarita Torrioni, Crónica festiva de dos reinados en la Gaceta de Madrid. 
tecnológicos ${ }^{9}$, e incluso notas de promoción personal de los redactores de la Gaceta ${ }^{10}$. La edición ordinaria de la Gaceta recogía las noticias de las principales capitales europeas y ultramar dispuestas en orden inverso a su proximidad geográfica, comenzando por las más lejanas hasta finalizar con las últimas noticias de Madrid. Como muestra recogemos el orden de los epígrafes contenidos en la Gaceta del 30 de noviembre de 1700: Varsovia, 23 de octubre; Hamburgo, 25 de octubre; Viena, 26 de octubre; Venecia, 26 de octubre; La Haya, 28 de octubre; Cádiz, 22 de noviembre y Madrid, 30 de noviembre.

\section{B.- Noticieros periódicos}

El primer número de la Gaceta de Madrid (año 1661) se abre con un preámbulo que justifica su edición ${ }^{11}$ : «Supuesto que en las más populosas ciudades de la Italia, Flandes, Francia y Alemania se imprimen cada semana (demás de las Relaciones de sucessos particulares) otras con título de Gazetas, en que se da noticia de las cosas más notables, assí políticas como militares, que han sucedido en la mayor parte del Orbe, será razón que se introduzga este género de impressiones, ya que no cada semana, por lo menos cada mes». Esta introducción pone de manifiesto la conciencia de su autor acerca de la diferencia existente entre las relaciones de sucesos particulares y las gacetas, diferencia que nosotros suscribimos ${ }^{12}$ :

\footnotetext{
${ }^{9} \mathrm{P}$. ej. la noticia de la llegada a la bahía de Cádiz de un pingue procedente de Tortosa, cargado con noventa troncos de gran tamaño para utilizar como arboladuras de navíos «aviéndose conducido de los Pirineos de Navarra, por inclusas o diques, a los ríos Esca, Aragón y Ebro hasta los Alfaques de Tortosa» [ $G d M, 30$ de noviembre de 1700].

${ }^{10}$ Así, al relatar la erección de un túmulo en memoria de Carlos II en la Capilla de las Descalzas de Madrid, se puntualiza: «y predicó el doctor don Juan de las Hebas» [GdM, 28 de diciembre de 1700].

${ }^{11}$ Titulada: Numero I. Relación o Gazeta de algunos casos particulares, assí politicos, como militares, sucedidos en la mayor parte del mundo hasta fin de diziembre de 1660. Puede verse una buena reproducción de la primera plana en el Suplemento extraordinario dedicado a la Gaceta por el BOE de 28 de febrero de 1961 [Centenario.GdM: 3], reproducción de donde tomamos la cita.

${ }^{12}$ No todos los catálogos (los catalogadores) de literatura efímera de carácter informativo están de acuerdo con tal diferenciación; o, si lo están, optan por incorporar a sus catálogos sujetos de una y otra especie aduciendo (no sin razón) que lo que las diferencias separan lo aproximan las semejanzas. A pesar de que las preocupaciones taxonómicas en torno a la literatura efímera de carácter informativo se ponen de manifiesto una y otra
} 
- Las relaciones de sucesos particulares son monotemáticas ${ }^{13}$ y no periódicas, sino ocurrentes: surgen a partir de un suceso, del cual dependen, y su edición es consecuencia (y por lo tanto posterior) al hecho relacionado: se escriben (y se editan) para relatar un suceso, y existen en función de ese suceso.

- Los noticieros periódicos y gacetas ${ }^{14}$ tienen carácter misceláneo y recurrente: concebidos como publicaciones periódicas son (en potencia) previas a las noticias que recogen, se surten de sucesos pero no se editan como consecuencia de esos sucesos.

El carácter serial de estos noticieros periódicos se pone de manifiesto tanto en los aspectos formales como en los contenidos. Siete (A-G, correspondientes al período enero-octubre de 1702) de los nueve ejemplares que se conservan en el legajo son prácticamente idénticos: encabezados por el título con composición epigráfica y en mayúsculas «Noticias extraordinarias y singulares del estado presente de la Europa» seguido,

\footnotetext{
vez en artículos, congresos, actas, etc., todavía se manifiestan las diferencias conceptuales, tanto, que casi es un tópico el hecho de que cada catálogo de piezas de esta literatura se encabece con la exposición del catalogador acerca de su concepto de relación (cronología, impresas $v r$. manuscritas, etc.). Por nuestra parte nos hacemos eco de la diferenciación que señala el profesor Ettinghausen: «Existían dos modelos fundamentales de folleto informativo. El primero [...] llevaba a menudo el título gaceta se parecía a un diario moderno en cuanto que se publicaba normalmente con regularidad (cada mes, cada semana, o, más raramente, cada día) y llevaba resúmenes provenientes de diversos lugares y países, con la pretensión de ofrecer un panorama de la actualidad. En concreto, solía poner el énfasis en sucesos políticos y militares ocurridos en el extranjero pero que podrían afectar indirectamente a sus probables lectores). El segundo modelo [...] se conocía en toda Europa bajo la denominación de relación. Redactadas muchas veces en forma epistolar [...] se dedicaba por extenso a un solo suceso» [Ettinghausen, Prensa: 339-340].

${ }^{13}$ Entendida esta monotematicidad en sentido laxo: no necesariamente se limitan a un suceso, pero cuando no es así existe algún vínculo entre los casos relatados. Sirva como ejemplo la relación titulada Triunfo glorioso, intercessión piadosa y eficacia del S.Rosario de nuestra Señora para con un hombre en 9 de febrero y para con una mujer en 8 de março de 1679... Escríbelos el muy reverendo Padre Maestro Fray Diego Carli, impresa en Barcelona por Rafael Figueró, seguramente en 1679, año al que se refieren los sucesos [Santos, Tormentas].

${ }^{14}$ Por supuesto incluimos en este grupo la Gaceta de Madrid que, si aparece diferenciada en el apartado anterior, es sólo como consecuencia de su función axial respecto a esta colección de informativos.
}

«CUADERNOS DE ESTUDIOS GALLEGOS», Tomo XLIX, Fascículo 115, Santiago 2002. 
en minúsculas, por el mes al que corresponden las noticias ${ }^{15} \mathrm{y}$ la fecha de publicación Estos noticieros constan de 4 hojas en $4^{\circ}$, paginadas (1-8) y con signatura tipográfica $\left(\mathrm{A}^{4}\right)$ independiente para cada número (a diferencias de la Gaceta, con paginación y signatura tipográfica correlativas para todo el año). El colofón, común a todos los ejemplares, indica el Privilegio de impresión, el lugar (Madrid) y el impresor (Antonio Bizarrón), aunque soslaya el año, quizá por la evidencia de la fecha que aparecía en el subtítulo.

Rompen con la uniformidad formal dos ejemplares: el catalogado con la letra $\mathrm{H}$ (noviembre de 1702), que altera el orden de los epítetos del título: singulares y extraordinarias, en el que se combinan mayúsculas y minúsculas, $\mathrm{y}$ en el que no aparece la fecha de publicación; y el ejemplar I (abril de 1704) que troca «extraordinarias» en «ordinarias» y en el que no figura el mes al que corresponde, sino sólo la fecha de su publicación. Además carece de colofón y de datos de impresión, y consta de dos hojas (en lugar de las cuatro habituales), lo que altera tanto la paginación (1-4) como la signatura tipográfica $\left(\mathrm{A}^{2}\right)$.

Respecto a la inserción de las rúbricas, los ejemplares que aquí comentamos mantienen un orden constante, alterado únicamente por la ausencia de algunas corresponsalías ${ }^{16}$ : Norte, Alemania, (Colonia: A), (Viena: A), Inglaterra, Holanda, (Flandes: A y C), Italia y Francia.

\section{C.- Relaciones de sucesos}

Intercaladas entre los ejemplares de la Gaceta se conservan quince relaciones de sucesos de los años 1702 y $1704^{17}$, catorce de ellas vinculadas por un nexo temático: el conflicto político-militar provocado por la muerte sin descendencia de Carlos II.

\footnotetext{
${ }^{15}$ La referencia al mes falta en A. Generalmente, el día de puesta a la venta de estos noticieros era el martes, aunque en algunos ejemplares (A y C) aparezca el sábado.

${ }^{16}$ Entre paréntesis las que aparecen de modo extraordinario, consignándose el ejemplar.

${ }^{17}$ Diez relaciones de 1702 (números 1-10 del Catálogo) y cinco de 1704 (números 11-15). Aunque sólo una de las relaciones consigna la fecha de edición (número 10), participamos de la tesis expuesta por María Remedios Moralejo según la cual «la fecha de impresión [...] aunque no está indicada, como suele ocurrir en este tipo de impresos, habitualmente coincide con la de los hechos relatados» [Moralejo, Zaragozanas: 490]; corrobora esta posibilidad, en el caso de las relaciones que nos ocupan, su inclusión en volúmenes anuales.
} 
El 2 de octubre de 1700, Carlos II firmaba en Madrid un testamento por el que dejaba como heredero de la Corona de España a Felipe de Anjou, nieto de Luis XIV. Con esta decisión, el último de los Habsburgo de la monarquía española trataba de garantizar la unidad de todos los $\operatorname{reinos}^{18} \mathrm{y}$ la independencia respecto a las coronas francesa y austríaca; pero cuando el duque de Abrantes abrazó al embajador de Austria, conde de Harrach, diciéndole: «Sire, es un placer; es un gran honor para toda mi vida, Sire, despedirme de la ilustrísima casa de Austria» [Kamen, GdS: 15] los diplomáticos y gobernantes europeos intuyeron que el advenimiento de Felipe de Anjou a la corona española rompía el endeble equilibrio europeo, dejando a los Borbones, abuelo y nieto, en una situación de manifiesta hegemonía. El sucesor de Carlos II llegaba a Irún el 22 de enero de 1701, con sólo diecisiete años de edad y la consideración, por parte de austríacos, holandeses e ingleses, de que se trataba de una marioneta en manos de Luis XIV, quien parecía querer ratificarlo con decisiones como la de concertar, sin previa consulta, la boda de su nieto con María Luisa Gabriela de Saboya ${ }^{19}$. El matrimonio se celebró en septiembre de 1701, unos días después de que Inglaterra, Austria y las Provincias Unidas de Holanda firmaran la Gran Alianza. El juego de interes había comenzado: Inglaterra y Holanda trataban de asegurar y controlar el comercio con las Indias y el tráfico con América, Austria se negaba a aceptar el final de su dinastía en España, y Portugal, que se uniría a la Gran Alianza en 1703, pretendía terminar con la preponderancia política de Castilla en la Península. Las tensiones en las plazas españolas del norte de Italia, ocupadas por Luis XIV en nombre de su nieto, y las revueltas en Nápoles, aconsejaban un viaje de Felipe V a Italia: embarcó en abril de

\footnotetext{
${ }^{18}$ Unos meses antes del fallecimiento de Carlos II, Luis XIV y Guillermo II de Inglaterra habían suscrito un tratado de partición de los reinos de España que adjudicaba Nápoles, Sicilia, Toscana, el Milanesado y Guipúzcoa al delfín de Francia, y Castilla, Navarra, Aragón, Flandes, las Indias y Filipinas al rey de Inglaterra. Este reparto no era una novedad: ya en 1668, Leopoldo I de Austria había firmado un tratado con el rey de Francia para estipular la división de los territorios españoles entre ambas coronas si Carlos II moría sin descendencia.

${ }^{19}$ María Luisa Gabriela de Saboya era hija de Víctor Amadeo II de Saboya, uno de los primeros soberanos que reconocieron a Felipe V, y de Ana María de Orleans. Tenía sólo trece años en septiembre de 1701, cuando se celebró su boda por poderes con Felipe $\mathrm{V}$, aunque los esposos no se conocieron personalmente hasta el mes de noviembre.
} 
1702 hacia Nápoles y, desde este reino, se trasladó a Milán. Entretanto, el 15 de mayo de 1702, la Gran Alianza había declarado la guerra a Luis XIV, y se iniciaba, de facto, la Guerra de Sucesión española.

Semejantes antecedentes justifican que el clima político de los primeros años del siglo XVIII en Europa, y particularmente en España, estuviera marcado por la inestabilidad, las tensiones políticas y, como culminación, el conflicto bélico. El clima de crisis y la aparición de dos facciones enfrentadas supuso una intensificación de la actividad impresora que se manifiestó en el «incremento excepcional de la publicación de folletos [...], las dos legitimidades en pugna luchan con la espada y con la pluma, en el campo de batalla y en el campo del pensamiento» [Pérez Picazo, Publicística: 22], y, añadimos nosotros, en el de la propaganda. La Guerra de Sucesión, conflicto internacional y guerra civil al mismo tiempo, dará lugar a un período especialmente fecundo de la literatura informativo-propagandística: publicaciones recurrentes y ocurrentes se suceden para dar cuenta de los motivos y las consecuencias de cada acción política o militar, y se multiplican los memoriales, las cartas, los romances ${ }^{20}$, las relaciones y los comentarios (serios o jocosos, en prosa o en verso, favorables a uno $\mathrm{u}$ otro de los contendientes), entretejiendo una red de impresos y manuscritos pendientes todavía (creemos) de un análisis conjunto. A pesar de que la voluntad informativa de sus redactores se subordine al propósito propagandístico, su interés como documentos históricos no mengua un ápice: son el reflejo de la manipulación ideológica y del control de las mentalidades en una época de crisis que combina los derechos sucesorios, la teología providencialista, la genealogía real y las profanaciones inherentes a pravedad herética (herejes desde la perspectiva de cualquiera de las dos facciones en conflicto), para justificar un conflicto dinástico que, amparándose en Borbones o Habsburgos, respondía a un enfrentamiento «por el dominio de Europa y por los mercados europeos de ultramar» [Kamen, Felipe V: 44].

En este ambiente se desarrollan las quince relaciones que catalogamos: catorce, directamente relacionadas con la Guerra de Sucesión, refieren o comentan, siempre desde la perspectiva de los defensores de la legi-

${ }^{20}$ Acerca de los romances de circunstancias escritos con motivo de la Guerra de Sucesión resulta muy interesante un reciente artículo en el que $\mathrm{M}^{\mathrm{a}}$ Pilar Cuesta cataloga 75 de estas composiciones, impresas entre 1701 y 1715 [Cuesta, Romances].

«CUADERNOS DE ESTUDIOS GALLEGOS», Tomo XLIX, Fascículo 115, Santiago 2002. 
timidad de Felipe V, las decisiones políticas y las acciones militares. Solamente una relación, la número 6 , es ajena al conflicto sucesorio, aunque su pertenencia al subgénero de las relaciones de redenciones de cautivos no la desvincula por completo de las connotaciones áulicas favorables al Monarca, representadas en este caso por la participación de la reina María Luisa de Saboya en la procesión de acción de gracias.

Giuseppina Ledda ha señalado de que los autores de relaciones bélicas: «ponen en práctica una evidente labor de selección de los acontecimientos, engarzándolos del mejor modo posible para afirmar y defender el mito del imperio, dejando en la sombra todo aquello que pudiera desdibujar este cuadro» [Ledda, Informar: 202]. La literatura de información bélica se convierte frecuentemente en literatura de propaganda de los ideales, de las banderas o de los promotores de esas acciones militares: sirve para animar a los combatientes y a la población que los sustenta, sobrevalorando los triunfos y minimizando (o convirtiendo en triunfos morales) las derrotas ${ }^{21}$. Aunque la mayor parte de las relaciones de género bélico refieran victorias de la bandera bajo la cual se escribe ${ }^{22}$ (vid. números 1 , 7,8 y 9), los resultados inciertos o las derrotas, convenientemente manipuladas, pueden servir como acicates ante una próxima batalla, o como instrumentos para poner de manifiesto la superioridad combativa, el valor o la protección divina de una de las facciones en conflicto; así en la relación número 14 , en la que no hay una armada victoriosa, se interpreta el resultado final como un éxito haciendo hincapié en la inferioridad numérica y armamentística y en que el viento era favorable al enemigo.

\footnotetext{
${ }^{21}$ Escribe José Saramago en Memorial do Convento, cuya acción se desarrolla en los tiempos de la Guerra de Sucesión: «E veio notícia de que no cerco de Campo Maior morreran muitos soldados inimigos e poucos dos nossos, se amanhâ nâo se disser que foran muitos dos nossos e poucos dos deles, ou ela por ela, que é o que virâo a dar as contas quando, ao ir acabar-se o mundo, se contarem os mortos de todos os lados».

${ }^{22} \mathrm{Al}$ respecto escribe Henry Ettinghausen, al referirse a las relaciones bélicas fruto de la Guerra de Secesión catalana, que «en Cataluña solamente se divulgaron (por lo menos de forma impresa) noticias de victorias ganadas por los franceses y de derrotas sufridas por los españoles» [Ettinghausen, Prensa: 343], aunque no es necesario ir tantos siglos atrás en el tiempo: basta hojear la prensa publicada por ambos bandos durante la Guerra Civil, las informaciones que proporcionaban los diferentes estados mayores durante la II Guerra Mundial, las noticias de Argelia, de Vietnan, de las Malvinas, de la Guerra del Golfo o, estos últimos meses (escribimos en abril de 2002), las informaciones de los bombardeos sobre Afganistán y del conflicto palestino-israelí.
} 
Hasta un derrota total puede trastocarse en victoria moral si se incide en el valor de los propios combatientes (subrayado por la narración de acciones heroicas) y en la disparidad de fuerzas en combate (siempre, claro está, favorables al enemigo); incluso la casualidad o la suerte, expresiones que la ortodoxia religiosa trastocaría en ayuda divina, puede menguar el peso de las derrotas convirtiéndolas en (parciales) victorias postmortem ${ }^{23}$.

\section{D.- Opúsculo político}

Un solo ejemplar pertenece a esta categoría; se trata de La verdad sin arte, y la justicia independiente. Manifiestas por un ministro de la razon, residente en Viena de Austria, en carta escrita a un político mantuano., folleto de 34 páginas en cuarto cuyos datos tipográficos se especifican a pie de portada: «Con permisso de los superiores. En Mantua, en la Imprenta Ducal: Por Juan Bautista Grana. Año M.D.CC.II.»

En la BUS se conservan dos ejemplares de este opúsculo: éste, ubicado entre Noticias extraordinarias del 17 de octubre de 1702 y $G d M$ del 24 de octubre de 1702, y otro con signatura: Foll. 305-11 [Bustamante, $\left.C B U-X V I I I \mathrm{n}^{\circ} 240\right]$.

\section{E.- Traslados manuscritos}

En el volumen de Gacetas correspondientes al año 1704 se hallan dos traslados manuscritos, posiblemente copias de documentos impresos:

1.- «Decreto que expidió Su Magestad el día 3 de marzo de 1704, antes de salir de la Corte».

Se trata de la copia simple de un Decreto de Felipe V indicando a quien compete la toma de decisiones cuando el Rey no está en Madrid. Data: «En Madrid a 3 de Marzo de 1704». Escrita sobre un folio doblado en dos hojas en cuarto, ocupando el texto el anverso y el reverso de la primera hoja. Ubicada entre $G d M$ del 4 de marzo de 1704 y $G d M$ de 11 de marzo de 1704.

${ }^{23}$ Don Diego Assensio de Vicuña, al referir la pérdida de dos galeones en combate con la escuadra anglo-holandesa hace especial hincapié en los daños causados a los navíos rivales y en el hundimiento de uno de los galeones españoles, cuando lo remolcaban como trofeo de guerra hacia Lisboa, que supuso la muerte de doscientos enemigos y la pérdida de toda la carga tomada como botín (vid $\mathrm{n}^{\circ} 12$ ).

«CUADERNOS DE ESTUDIOS GALLEGOS», Tomo XLIX, Fascículo 115, Santiago 2002. 
2.- «Horden para las nuebas Compañías de Guardias de el Rey nuestro Señor en Junio de 1704».

Copia simple de una Orden de Felipe V dando instrucciones a su guardia personal. Escrita sobre un folio doblado en dos hojas en cuarto, manuscritas ambas por anverso y reverso. Ubicada entre $G d M$ del 17 de junio de 1704 y $G d M$ del 2 de septiembre de 1704.

\section{CRITERIOS DE TRANSCRIPCIÓN Y CATALOGACIÓN}

\section{Criterios de transcripción}

Los títulos de los ejemplares catalogados se transcriben con la mayor exactitud posible: ortografía, puntuación, distribución por líneas y utilización de mayúsculas y minúsculas; unificamos en la grafía $s$ tanto la $s$ alta como la $s$ baja. Para facilitar la lectura, los títulos y las citas entresacadas de textos antiguos se aligeran de la exactitud descriptiva, acentuando y puntuando de acuerdo a las actuales normas ortográficas.

Modelo de ficha catalográfica:

- Número de documento.

- Autor: en el caso de las atribuciones el nombre figura entre corchetes.

- Título: título completo, reflejando mediante barras la distribución por líneas.

a) Datos tipográficos ${ }^{24}$ : Fecha de impresión. || Lugar de impresión. || Impresor. || Editor. || Transcripción íntegra del pie de imprenta o del colofón.

b) Características externas: Formato. || Foliación. || Signatura tipográfica. || Título: ubicación (portada independiente o título en cabecera) y composición. || Iniciales. || Ilustraciones: descripción sucinta, medidas y localización. || Ornamentos: descripción sucinta,

\footnotetext{
${ }^{24}$ Las atribuciones figuran entre corchetes. Un asterisco volado $\left(^{*}\right)$ significa que los datos tipográficos no constan de manera explícita, sino que se deducen del contenido del texto. Consideramos que la fecha de impresión, aunque no esté indicada, coincide generalmente (a excepción de las reimpresiones), con la de los hechos narrados [Moralejo, Zaragozanas: 490].
} 
medidas y localización. || Reclamos, manecillas y notas marginales impresas.

c) Contenido: Tema o temas ${ }^{25}$. || Idioma. || Prosa / verso. || Fórmulas de reconocimiento editorial.

d) Ubicación del impreso en el legajo BUS: Public Diaria-48 (17001704). Dado que al legajo carece de foliación, situamos cada ejemplar a partir del que lo precede y el que lo sigue.

e) Otros ejemplares idénticos: Recogemos en este apartado sólo aquellos ejemplares que hemos podido cotejar y de cuya identidad con el catalogado podemos dar fe.

f) Otros ejemplares. Ejemplares aparentemente idénticos que no hemos podido cotejar.

- Observaciones: estructura, sinopsis argumental, dataciones, etc.

\section{CATÁLOGO DE LAS NOTICIAS EXTRAORDINARIAS}

\section{A}

+ / NOTICIAS / EXTRAORDINARIAS, / Y SINGVLARES, / DEL ESTADO PRESENTE DE LA EUROPA. / Publicadas el Sabado 22. de Enero de 1702

a) [1702]* || Madrid || Antonio Bizarrón || s.ed. || Colofón: «CON PRIVILEGIO / < filete segmentado> / En Madrid: Por Antonio Bizarrón».

b) $4^{\circ} \| 8 \mathrm{pp}$. $\left\|\mathrm{A}^{4}\right\|$ Cabecera con composición epigráfica $\|$ Inicial simple de tres líneas || Reclamos (Los / El / sea / dien- / na / escu- / En).

c) Gaceta || Castellano || Prosa || Noticias extraordinarias y singulares.

d) BUS. Public.Diaria-48 (1700-1704). Entre $G d M$ 17.enero.1702 y GdM 24.enero. 1702

e) -

f) -

\footnotetext{
${ }^{25}$ Para sentar las bases de esta clasificación elaboramos previamente un corpus temático a partir de algunos catálogos de relaciones de sucesos [Agulló, RS.1; Agulló, RS.2; $R S . F e l i p e$ III y Pena, RS.Coruña] que nos permitió tener una visión general de temas recurrentes y derivados.
} 
Epígrafes: Norte.- Alemania.- Colonia.- Viena.- Inglaterra.- Holanda.Flandes.- Italia.- Francia.

Suponemos ésta una variante de estado de las Noticias extraordinarias y singulares del estado presente de la Europa. Publicadas el Sabado 28. de Enero de 1702., puesto que tanto la composición como el contenido de ambas es idéntico, difiriendo únicamente en la fecha: «22» y «28» respectivamente. Sin duda el ejemplar que catalogamos corresponde al primer estado de la edición; advertido el notable error que podía implicar un descenso de las ventas al anunciar noticias atrasadas, se detendría la impresión para efectuar la sustitución del tipo «2» por el «8», dando lugar al segundo estado de esta edición, con la fecha correcta, de la que se conserva un ejemplar en la BUS, con signatura: Foll.303-26 [Bustamante, $\left.C B U-X V I I I \mathrm{n}^{\circ} 222\right]$.

\section{B}

+ / NOTICIAS / EXTRAORDINARIAS, / Y SINGVLARES, / DEL ESTADO PRESENTE DE LA EUROPA, / en el mes de Abril de 1702. / Publicadas el Martes 11. de Abril de 1702.

a) [1702]* || Madrid || Antonio Bizarrón || s.ed. || Colofón: «CON PRIVILEGIO / < filete segmentado> / En Madrid: Por Antonio Bizarrón».

b) $4^{\circ} \| 8$ pp. $\left\|\mathrm{A}^{4}\right\|$ Cabecera con composición epigráfica || Inicial simple de dos líneas || Reclamos (puer- / el / El / Orien- / sus / pu- / cido).

c) Gaceta || Castellano || Prosa || Noticias extraordinarias y singulares.

d) BUS. Public.Diaria-48 (1700-1704). Entre $G d M 4$.abril.1702 y $G d M$ 11.abril.1702.

e) -

f) -

Epígrafes: Norte.- Alemania.- Inglaterra.- Holanda.- Italia.- Francia.

\section{C}

+ / NOTICIAS / EXTRAORDINARIAS / Y SINGVLARES, / DEL ESTADO PRESENTE DE LA EUROPA, / en el mes de Abril de 1702. / Publicadas el Sàbado 29. de Abril de 1702.

a) [1702]* || Madrid || Antonio Bizarrón || s.ed. || Colofón: «Con Privilegio. En Madrid: Por Antonio Bizarrón». 
b) $4^{\circ}$ || 8 pp. || $\mathrm{A}^{4}$ || Cabecera con composición epigráfica. || Inicial simple de dos líneas. || Reclamos (El / avía / que / Olan- / Sobe- / pos / Druy).

c) Gaceta \| Castellano \| Prosa || Noticias extraordinarias y singulares.

d) BUS. Public.Diaria-48 (1700-1704). Entre Copia de carta ... Monsieur de Torsi y GdM 2.mayo.1702.

e) -

f) Madrid. RAH: $11 / 9391 \mathrm{n}^{\circ} 650$ [CCPB $\left.\mathrm{n}^{\circ} 334284\right]$.

Epígrafes: Norte.- Alemania.- Inglaterra.- Holanda.- Flandes.- Italia.Francia.

\section{D}

+ / NOTICIAS / EXTRAORDINARIAS, / Y SINGVLARES, / DEL ESTADO PRESENTE DE LA EUROPA, / en el mes de Mayo de 1702. / Publicadas el Martes 13. de Junio de 1702.

a) [1702]* || Madrid || Antonio Bizarrón || s.ed. || Colofón: «CON PRIVILEGIO / < filete segmentado> / En Madrid: Por Antonio Bizarrón».

b) $4^{\circ} \| 8 \mathrm{pp}$. $\left\|\mathrm{A}^{4}\right\|$ Cabecera con composición epigráfica || Inicial simple de dos líneas || Reclamos (de / mil / porte / hazer / daño. / El / To-).

c) Gaceta $\|$ Castellano $\|$ Prosa $\|$ Noticias extraordinarias y singulares.

d) BUS. Public.Diaria-48 (1700-1704). Entre $G d M$ 13.junio.1702 y GdM 20.junio.1702.

e) -

f) Madrid. RAH: 11/9391 no 652 [CCPB $\left.\mathrm{n}^{\circ} 334286\right]$.

Epígrafes: Norte.- Alemania.- Inglaterra.- Holanda.- Italia.- Francia.

\section{$\mathbf{E}$}

+ / NOTICIAS / EXTRAORDINARIAS, / Y SINGVLARES, / DEL ESTADO PRESENTE DE LA EUROPA, / por el mes de Junio de 1702. / Publicadas el Martes 18. de Julio de 1702.

a) [1702]* || Madrid || Antonio Bizarrón || s.ed. || Colofón: «CON PRIVILEGIO / < filete segmentado> / En Madrid: Por Antonio Bizarrón».

b) $4^{\circ} \| 8 \mathrm{pp}$. $\left\|\mathrm{A}^{4}\right\|$ Cabecera con composición epigráfica $\|$ Inicial simple de dos líneas || Reclamos (po- / que / quie- / veían / qua- / na / Para).

c) Gaceta || Castellano || Prosa || Noticias extraordinarias y singulares. 
d) BUS. Public.Diaria-48 (1700-1704). Entre $G d M$ 18.julio.1702 y GdM 25.julio. 1702

e) -

f) Madrid. RAH: 11/9391 no 653 [CCPB no 334287].

Epígrafes: Norte.- Alemania.- Inglaterra.- Holanda.- Italia.- Francia.

\section{F}

+ / NOTICIAS / EXTRAORDINARIAS / Y SINGVLARES, / DEL ESTADO PRESENTE DE LA EUROPA, / por el mes de Agosto de 1702. / Publicadas el Martes 12. de Septiembre de 1702.

a) [1702]* || Madrid || Antonio Bizarrón || s.ed. || Colofón: «CON PRIVILEGIO / < filete segmentado> / En Madrid: Por Antonio Bizarrón»».

b) $4^{\circ} \| 8$ pp. $\left\|\mathrm{A}^{4}\right\|$ Cabecera con composición epigráfica \|Inicial simple de dos líneas || Reclamos (La / trem- / pues / dia / que- / ha/ prue-).

c) Gaceta. || Castellano || Prosa || Noticias extraordinarias y singulares.

d) BUS. Public.Diaria-48 (1700-1704). Entre GdM12.septiembre.1702 y $G d M 19$. septiembre.1702.

e) -

f) Madrid. RAH: $11 / 9391 \mathrm{n}^{\circ} 654$ [CCPB no 334288].

Epígrafes: Norte.- Alemania.- Inglaterra.- Holanda.- Italia.- Francia.

\section{G}

+ / NOTICIAS / EXTRAORDINARIAS, / Y SINGVLARES / DEL ESTADO PRESENTE DE LA EUROPA, / por el mes de Septiembre de 1702. / Publicadas el Martes 17. de Octubbre de 1702.

a) [1702]* || Madrid || Antonio Bizarrón || s.ed. || Colofón: «CON PRIVILEGIO / < filete segmentado> / En Madrid: Por Antonio Bizarrón».

b) $4^{\circ} \| 8 \mathrm{pp}$. $\left\|\mathrm{A}^{4}\right\|$ Cabecera con composición epigráfica $\|$ Inicial simple de dos líneas || Reclamos (Sio- / Del / guen / victo- / ra / Fran- / El).

c) Gaceta || Castellano || Prosa || Noticias extraordinarias y singulares.

d) BUS. Public.Diaria-48 (1700-1704). Entre Copia de carta ... Munich y $L a$ verdad sin arte. 
e) -

f) Madrid. BN: V.E.690 (52) [Aguilar Piñal, $B A E-9 \mathrm{n}^{\circ}$ 4158]. || Madrid. BN: V.C.121 (27) [Aguilar Piñal, $B A E-9 \mathrm{n}^{\circ}$ 4158]. || Madrid. RAH: 11/9391 no 655 [CCPB n $\left.{ }^{\circ} 334284\right]$.

Epígrafes: Norte.- Alemania.- Inglaterra.- Holanda.- Italia.- Francia.

\section{$\mathbf{H}$}

+ / NOTICIAS / SINGVLARES, Y EXTRA-/ordinarias de el estado presente de / la Europa, por el mes de / Noviembre de / 1702.

a) [1702]* || Madrid || Antonio Bizarrón || s.ed. || Colofón: «CON PRIVILEGIO / En Madrid: Por Antonio Bizarrón».

b) $4^{\circ} \| 8 \mathrm{pp}$. || $\mathrm{A}^{4} \|$ Cabecera con composición en base de lámpara $\|$ Inicial simple de cuatro líneas || Reclamos (Gue- / Los / por- / Olan/ de- / Los / mis).

c) Gaceta || Castellano || Prosa || Noticias singulares y extraordinarias.

d) BUS. Public.Diaria-48 (1700-1704). Entre GdM28.noviembre.1702 y $G d M$ 5.diciembre. 1702 .

e) -

f) -

Epígrafes: Norte.- Alemania.- Inglaterra.- Holanda.- Italia.- Francia.

\section{$\mathbf{I}$}

+ / NOTICIAS SINGVLARES, / Y ORDINARIAS / DEL ESTADO PRESENTE DE EUROPA, PVBLICADAS / en Madrid à 12. de Abril de 1704.

a) $[1704]^{*} \|$ [Madrid] || s.i. || s.ed. || s.d.t.

b) $4^{\circ} \| 2$ hs. $\left\|\mathrm{A}^{2}\right\|$ Cabecera con composición epigráfica \| Inicial simple de dos líneas || Reclamos (Rio / y /pre-).

c) Gaceta || Castellano || Prosa || Noticias singulares y ordinarias.

d) BUS. Public.Diaria-48 (1700-1704). Entre GdM8.abril.1704 y $G d M$ 15.abril.1704.

e) -

f) -

Epígrafes: Norte.- Alemania.- Inglaterra.- Holanda.- Italia.- Francia. 


\section{5.- CATALOGO DE LAS RELACIONES DE SUCESOS}

\section{1}

+ / NOTICIA PARTICVLAR, / DEL SUCESSO DE CREMONA, QVE / sucediò el dia primero de Febrero de 1702. invadi-/da por los Imperiales, y defendida con valor / indecible de la Guarnicion de las Tro-/pas Aliadas. / Publicada el dia 13. de Março.

a) s.a [1702]* || Madrid || Antonio Bizarrón || s.ed. || Colofón: «Con Privilegio: En Madrid: Por Antonio Bizarrón».

b) $4^{\circ} \| 2$ hs. || s.sign. || Cabecera: composición epigráfica || Inicial simple de cuatro líneas || Reclamos (Man / dos / ta).

c) Militar: asalto || Castellano || Prosa || Noticia particular.

d) BUS: Public.Diario-48 (1700-1704), ubicado entre $G d M$ de 7 de marzo de 1702 y $G d M$ de 14 de marzo de 1702 .

e) BUS: Foll.225-11 [Bustamante, $C B U-X V I I I \mathrm{n}^{\circ}$ 221.- Pena, RS.Coruña $\mathrm{n}^{\circ}$ 264.- Aguilar Piñal, $\left.B A E-9 \mathrm{n}^{\circ} 4094\right]$ ].

f) Madrid. RAH.11/9391 $\mathrm{n}^{\circ} 632$ [CCPB $\mathrm{n}^{\circ}$ 334260]. \| Madrid. BN: V.ER.690 (57) [Aguilar Piñal, $B A E-9 \mathrm{n}^{\circ} 4094$ ] || Granada. Biblioteca Universitaria: A-31-259 (11) [Aguilar Piñal, BAE-9 n ${ }^{\circ} 4094$ ] ॥ Lisboa. Biblioteca del Palacio de Ajuda: 55-III-13/2 [CRS-BGP, s.n.]. || París. Bibliotheque Nationale de France: OD-28, Tolbiac. [BNF $\mathrm{n}^{\circ}$ 33506213].

Pormenorizada relación del fallido intento imperial de tomar la ciudad de Cremona durante la noche del 31 de enero de $1702^{26}$. Posibilitó la acción un eclesiástico llamado Cuceli, párroco de Santa María la Nueva, al franquear la entrada en la ciudad a través de su casa a una avanzadilla de las tropas imperiales que, aprovechando la oscuridad, abrieron las puertas de Cremona para dar paso a tres mil corazas, tres mil granaderos y quinientos húsares bajo el mando del príncipe Eugenio y el conde Comerci.

Convocados los principales ciudadanos de Cremona por el príncipe Eugenio, se les propuso que juraran fidelidad al Emperador, a lo que los cremoneses, representados por el conde Esquizi Quinquineli, se negaron

${ }^{26}$ Tanto el marqués de Ribas [Ubilla, Successión: 365-369], contemporáneo de los sucesos y secretario del Despacho Universal de Felipe V, como el marqués de San Felipe [Bacallar, Comentarios: 37-38], ofrecen una minuciosa narración de la toma de Cremona.

«CUADERNOS DE ESTUDIOS GALLEGOS», Tomo XLIX, Fascículo 115, Santiago 2002. 
alegando haber jurado fidelidad a Felipe V: «y ellos querían más perder sus casas, libertad y haziendas, que infamar su nombre» (h.1v). Entretanto, los soldados que guardaban la guarnición, repuestos de la sorpresa, emprendieron la contraofensiva en la que murió el gobernador de la Plaza, don Diego de la Concha, y resultó gravemente herido monsieur de Crenant.

A pesar de lo encarnizado del combate, que cubrió la calles de Cremona de sangre, agonizantes y cadáveres, el relator se detiene en la descripción de algunos episodios jocosos -si se despojan de la crueldad de la situación- que sirven para contraponer la ingenuidad del enemigo al ingenio de los soldados borbónicos; así, el anónimo cronista relata como el príncipe Eugenio envió un oficial para que persuadiese a los irlandeses que defendían el cuerpo de guardia a rendirse «con la promessa de mantenerles su sueldo y hazer a cada uno particular merced. Pero ellos respondieron al oficial que se acercasse más, que no lo oían, y él, creyendo la propuesta, se acercó tanto que lo cogieron prisionero de guerra, y con más fuego dieron la última respuesta a los imperiales» (h.2r).

Paulatinamente, y a pesar de los pésimos augurios de los primeros momentos de la batalla, la victoria va decantándose a favor de las tropas establecidas en Cremona. En este sentido resulta decisiva la acción de un grupo de soldados franceses que cortaron las cuerdas del puente sobre el Po imposibilitando a las tropas imperiales, asentadas al otro lado del río, el envío de refuerzos a los imperiales. El príncipe Eugenio, en vista de la férrea defensa ejercida por el ejército borbónico con la colaboración de los cremoneses, consciente de la imposibilidad de que los refuerzos establecidos en la ribera opuesta del Po llegaran en su auxilio, y advirtiendo la inminente derrota, ordenó la retirada después de once horas de combate.

Concluye la relación con el balance de las bajas, aproximadamente dos mil muertos, además de un millar de heridos y medio millar de prisioneros de las tropas imperiales, frente a los cuatrocientos muertos y otros tantos heridos de los defensores. El relator agradece a los cremoneses su fidelidad a Felipe $\mathrm{V}$ y la caridad que demostraron al socorrer a la guarnición con víveres y otras provisiones.

En la Gaceta de Madrid de fecha 7 de marzo de 1702 (pp.39-40) se recoge una noticia fechada en Cremona el 6 de febrero del mismo año que relata esta acción en términos semejantes, aunque de manera más escueta. Así mismo, en las Noticias extraordinarias... fechadas el 29 de abril se vuelve a hacer referencia a esta batalla, poniéndose de manifiesto la im- 
portancia de su resultado final en la evolución del conflicto sucesorio: «Después del sucesso de Cremona, han desmayado mucho los ánimos para entrar el pie en el Milanés; y assí quedan las tropas imperiales entre el Oglio y el Cremonés acechando nuevas ocasiones» (p. 2).

\section{2}

+ / RELACION DE LAS CEREMONIAS, Y FESTEJOS / publicos que se hizieron en Bruselas en 21. de Febrero 1702. / para la Inauguracion del muy alto, y muy poderoso Principe / Philipe Quinto, Rey de España, y de las Indias, como Duque / de Lothier, de Brabante, de Limbourg, y Marquès del Santo / Imperio.

a) s.a. [1702]* || s.l. || s.i. || s.ed. || s.d.t.

b) $4^{\circ} \| 4$ pp. || s.sign. || Cabecera: línea tirada || Inicial simple de dos líneas $\|$ Reclamos (El / va / otra).

c) Política: juramento real.- Festiva: proclamación real || Castellano \| Prosa || Relación.

d) BUS: Public.Diario-48 (1700-1704), ubicado entre $G d M$ de 21 de marzo de 1702 y $G d M$ de 28 de marzo de 1702 .

e) -

f) Madrid. RAH: 11/9389 $n^{\circ} 530$ [CCPB $\mathrm{n}^{\circ} 354844$, con ligeras variantes ortográficas en el título] \| Madrid. Fundación Lázaro Galdiano $\mathrm{n}^{\circ} 13551$ [Aguilar $B A E-9 \mathrm{n}^{\circ}$ 5264]. || París. Bibliotheque Nationale de France: OD-28, Tolbiac. [BNF $\left.\mathrm{n}^{\circ} 33578313\right]$.

Relación de las ceremonias celebradas en Bruselas el día 21 de febrero de 1702, en las que el marqués de Bedmar juró, en nombre de Felipe $\mathrm{V}$ y como duque de Lothier, de Brabante, de Limbourg y marqués del Santo Imperio, las constituciones, leyes, privilegios y prerrogativas de las Provincias.

Las ceremonias de juramento comenzaron a las diez de la mañana del día 21, cuando los representantes de los Estados ${ }^{27}$ acompañaron al Marqués a la iglesia de Santa Gudula donde, ante un altar erigido para la ocasión, celebró una misa solemne el obispo de Amberes. Acabada la

${ }^{27}$ Se trata de los diputados de los estados de Limbourg y de Ultra-Moso, los recibidores, los diputados de Amberes, Bruselas y Lovaina, los nobles y los abades. En la Relación se ofrece el nombre de cada uno de ellos.

«CUADERNOS DE ESTUDIOS GALLEGOS», Tomo XLIX, Fascículo 115, Santiago 2002. 
misa, el marqués de Bedmar juró en nombre de Felipe $\mathrm{V}$ y ante el arzobispo de Malinas conservar los derechos de las iglesias de las Provincias. Posteriormente la comitiva se dirigió al Palacio, donde el marqués de Bedmar juro, de nuevo ante el arzobispo de Malinas, mantener todos los privilegios, franquezas y derechos antiguos $\mathrm{y}$, a continuación, los estados juraron fidelidad, obediencia y vasallaje al Rey, finalizando con las acostumbradas exclamaciones que «el pueblo repitió diferentes vezes con demostraciones de regocijo extraordinario y muestras singulares del amor que el pueblo tiene a su nuevo monarca, redoblándose estas aclamaciones al tiempo que los diputados de la Cámara de Cuentas de Brabante echaron una gran cantidad de piezas de oro y plata representando de una parte el retrato del Rey y de la otra un Sol oriente» (pp.3-4); no se cuida el relator de ocultar el motivo monetario del regocijo popular.

Acabadas estas ceremonias se celebró un banquete y, por la noche, un baile al que asistió toda la nobleza; para el común, las luminarias, los fuegos, las salvas de mosquete de las cinco compañías de burgueses de la ciudad, el son de la campana grande y la artillería de las murallas, acompañado todo ello de «tres fuentes de vino en la Plena del Parque» (p.4) subrayaron el carácter festivo de la jornada. Las ceremonias del día siguiente volvieron a abrirse con una misa en la iglesia de Santa Gudula y se reprodujeron los festines gastronómicos y las celebraciones en las calles.

Añade el relator que esta función se repitió, con la misma solemnidad y alborozo, en las demás provincias de estos países «excepto en la provincia de Flandes, adonde es menester vaya Su Excelencia en persona, para cuya función se están haziendo las disposiciones necessarias» (p.4).

Como cierre de la relación se estampó la leyenda ${ }^{28}$ : PHILIPPVS QVINTVS HISPANIAE MONARCHA INAVGVRATVN / DUX BRABANTIAE.

3

TORCY. Jean Baptiste Colbert, marqués de + / COPIA DE CARTA / TRADUCIDA EN ESPAÑOL, QUE / de orden del Rey Christianissimo escri-/vio Monsieur de Torsi a los / Estados de Olanda.

${ }^{28}$ Subrayamos las letras que aparecen en la leyenda con cuerpo de mayor tamaño. 
a) s.a [1702?] || Madrid || Antonio Bizarrón || s.ed. || Colofón: «CON PRIVILEGIO / En Madrid: Por Antonio Bizarrón».

b) $4^{\circ} \| 2$ hs. $\left\|\mathrm{A}^{2}\right\|$ Cabecera: composición epigráfica $\|$ Inicial simple de dos líneas || Reclamos (plean- / sin- / se).

c) Política: relaciones internacionales. || Castellano. || Prosa. || Copia de carta.

d) BUS: Public.Diario-48 (1700-1704), ubicado entre $G d M$ de 25 de abril de 1702 y Noticias extraordinarias ... 29 de abril de 1702 .

e) BUS: RSE.Var III/14 [Bustamante, $C B U-X V I I I \mathrm{n}^{\circ}$ 12352.- Aguilar $\left.B A E-9 \mathrm{n}^{\circ} 1323\right]$.

f) Madrid. RAH 11/9391 no 634 [CCPB no 281508] || Coimbra. Biblioteca Geral Universitaria: Misc.XXXIII-75729.

Copia de la amenazadora carta que el marqués de Torcy, por orden de Luis XIV, escribió a los representantes de los titulados de Holanda.

Comienza la misiva dando un ultimátum a los estados de Holanda: «antes que el Rey [Luis XIV] se vea obligado a empezar alguna operación militar con los numerosos exércitos que tiene juntos» (h.1r). En la carta se presenta a Luis XIV como un monarca complaciente y comprensivo con Holanda «un Estado que Su Magestad mira todavía con cariño» (h.1v), preocupado por salvaguardar la tranquilidad de sus ciudadanos y por fomentar sus actividades comerciales; pero «los tratados hechos con los enemigos del rey de España, contra él y su nieto [...], los actos de hostilidad [...], averse negado a examinar los derechos de entrada y salida del rey de España y los de las Provincias Unidas [...], las empressas hechas contra los aliados de Su Magestad y [...] los socorros dados públicamente para atacarlos» (h.1v) han trastocado la amistosa situación anterior. A pesar de todo ello, el rey Sol se brinda a olvidar esta conducta de los estados de Holanda y, renovando la antigua amistad, asegurar el comercio holandés y los privilegios y ventajas que sus ciudadanos han gozado siempre, tanto en Francia como en España, ofreciendo la confirmación de los tratados de Nimega, Riservik y Munster a cam-

\footnotetext{
${ }^{29}$ Aprovecho esta nota para agradecer a Nieves Pena Sueiro sus amables indicaciones en torno al universo de las Relaciones de sucesos, en el que es una destacada especialista, entre ellas la información epistolar que me ha proporcionado acerca de este ejemplar, el número 129 de su tesis [Pena, Repertorio].
} 
bio de que los holandeses salgan de las posesiones españolas y abandonen las armas.

Afirma el marqués de Torcy que si los estados holandeses aceptan sus condiciones, la seguridad de las provincias está asegurada y la paz y la libertad volverán juntas:

Aora depende sólo de vuestras señorías [...], o la quietud y libertad, o la guerra y la ruina de su comercio, sacrificándole a extraños intereses. El tiempo de empezar la campaña se acerca; los exércitos de Su Magestad están promptos y en aptitud de entrar en operación. La prudencia de vuestras señorías les dictará [...] quál partido deben elegir para el bien de la patria y para la inmortal gracia de vuestras señorías. (h.2r-v).

En febrero de 2002 adquirimos en la Librería Anticuaria de Oviedo un ejemplar de este impreso que responde exactamente a las características de los dos que se guardan en la BUS, difiriendo sólo en la ausencia de colofón de nuestro ejemplar. Que los tres ejemplares proceden de la misma prensa es evidente, ya que se repiten hasta los más pequeños detalles (p. ej. la deficiente impresión de la «g» de «Magestad» (h.lr., línea 13) o de la última «a» de «-pleándolas» (h.1v., línea 1), por lo que podemos considerar ésta una variante de estado de la edición. Otro ejemplar, sin colofón, se encuentra en la Biblioteca Nacional de Francia $\left[B N F \mathrm{n}^{\circ}\right.$ 31957535].

\section{4}

+ / NOTICIAS / EXTRAORDINARIAS, / Y DIARIO / DEL FELIZ VIAGE DEL REY N.SEÑOR, / desde el día 8. de Abril, que se embarcò en Barce-/lona, hasta el dia 16. del mismo mes, / que llegò dichosamente à / Napoles. / Publicadas el día 3. de Mayo de 1702.

a) s.a. [1702]* || Madrid || Antonio Bizarrón || s.ed. || Colofón: «CON PRIVILEGIO/ < filete segmentado> / En Madrid: Por Antonio Bizarrón»».

b) $4^{\circ} \| 2$ hs. || $\mathrm{A}^{2}$ || Cabecera: composición epigráfica || Inicial simple de 3 líneas || Reclamos (bes: / ce- / sen).

c) Política: viaje real || Castellano || Prosa || Noticias extraordinarias.Diario.

d) BUS: Public.Diario-48 (1700-1704), ubicado entre $G d M$ de 2 de mayo de 1702 y $G d M$ de 9 de mayo de 1702. 
e) -

f) Madrid. BN: V.E. 712 (65) [Aguilar $B A E-9 \mathrm{n}^{\circ} 4151$ ] $\|$ Madrid. BN: V.E. 690 (58) [Aguilar $B A E-9 \mathrm{n}^{\circ}$ 4151] || Granada. Biblioteca Universitaria: A-31-259 (10) [Aguilar $B A E-9 \mathrm{n}^{\circ} 4151$ ]. || Lisboa. Biblioteca del Palacio de Ajuda: 55-III-18/32 [CRS-BGP, s.n]. || Lille. Mediatheque Jean Levy: 14625 [CCFR s.n.].

Breve relación del viaje de Felipe $\mathrm{V}$ a Nápoles, salpicada con detalles de los avatares propios de la navegación que partió de Barcelona a las seis de la tarde del sábado 8 de abril de 1702, avistando Mallorca el día 10, y la isla de Cerdeña dos días después, 12 de abril, víspera de Jueves Santo. Se detallan los oficios del Viernes Santo, predicados en francés por el padre confesor, y la dieta de pescado que los componentes de la expedición realizaron de ese día. A las seis de la tarde del domingo, día 16, arribó el navío real al puerto de la bahía, distante dos leguas de la ciudad de Nápoles; los lugareños recibieron entusiasmados a la comitiva y la ciudad de Puzol envió a sus comisarios a besar la mano de Felipe V. En la tarde del 17 de abriil ${ }^{30}$ desembarcó en Nápoles la comitiva real, desde donde se envió un despacho a la reina María Luisa que se hallaba en Zaragoza. La noticia de la llegada de Felipe V a Nápoles, recibida en la capital aragonesa el 29 de abril, provocó «grandes demonstraciones de alegría» (h.2v), y humaniza la imagen de una Reina que, desasosegada ante el largo viaje por mar de su marido, queda «singularmente gustosa por aver salido del cuidado» (h.2v) al recibir la noticia.

A partir de este momento pasa a ser la Reina el centro de atención de la relación: se refiere «el juramento en la Iglesia del Asseo» (h.2v) que hizo María Luisa de Saboya el día 26 de abril y la posibilidad de que se cierren las Cortes aragonesas sin que se nombre presidente.

El último párrafo del impreso recoge dos noticias de carácter divergente: la primera, acerca del comienzo de una novena en el Pilar, contrasta con la mundanal secularidad de la segunda: «Ha salido la reforma del trage de las señoras, saliendo ya las damas con la nueva moda» (h.2v).

${ }^{30}$ Difieren las fechas que proporciona esta relación de las del marqués de San Felipe [Bacallar, Comentarios: 39]; según éste, Felipe V embarcó en Barcelona el día 1 de mayo y entró en Nápoles el 29 del mismo mes.

«CUADERNOS DE ESTUDIOS GALLEGOS», Tomo XLIX, Fascículo 115, Santiago 2002. 
La más prolija narración (que conocemos) del viaje de Felipe $\mathrm{V}$ a Nápoles puede verse en las pp. 881-438 de Successión de el rey D.Phelipe $V$, publicada en Madrid, por Juan García Infanzón, en 1704 y en la que su autor, Antonio de Ubilla y Medina, secretario del Despacho Universal del Rey, recoge la actividad diaria de Felipe V desde el fallecimiento de Carlos II hasta el regreso a Madrid al final de la campaña italiana del Monarca. Además de la minuciosa narración de los hechos, ofrece la transcripción de documentos y cartas y una serie de espléndidos grabados comentados que ilustran los acontecimientos más destacados. En relación con el viaje napolitano, dos calcografías de gran tamaño $(65 \times 49$ $\mathrm{cm}$ ) diseñadas en 1703 por Philippo Pallota ${ }^{31}$, grabadas por J.B.Berterham e impresas en Bruselas por E.H.Fritx, recogen el «Embarco del Rey N.S. en el muelle de Barcelona para passar a Ytalia ... el día ocho del mes de abril de este año de MDCCII» y el «Desembarco del Rey N.S. delante de la Baýa de Nápoles».

\section{5}

+ / PUNTVAL, Y SINCERA RELACION / de la Real Cavalgata, con que solemnizo la No-/vilissima, y fidelissima Ciudad de Napoles el dia / 20. de Mayo de este año la entrada publica de / Nuestro gloriosissimo Monarca Rey, y Señor Don / Phelipe V. que Dios guarde.

a) s.a [1702]* || s.l. || s.i. || s.ed. || Colofón: «CON PRIVILEGIO».

b) $4^{\circ} \| 4$ hs $\left\|\mathrm{A}^{4}\right\|$ Cabecera: composición a línea tirada, con sangría francesa || Inicial simple de cuatro líneas || Reclamos (de / Guar- / el / Ca- / su / IN- / Du- ).

c) Política: viaje real.- Ceremonias y festejos: desfile || Castellano \| Prosa || Puntual y sincera relación.

d) BUS: Public.Diario-48 (1700-1704), ubicado entre $G d M$ de 20 de junio de 1702 y GdM de 27 de junio de 1702 .

e) -

\footnotetext{
${ }^{31}$ Acerca de los grabados, cuadros y dibujos realizados por Philippo Pallota para ilustrar episodios de la Guerra de Sucesión (p.ej: La partida de Felipe V a la campaña de Portugal, los diseños para los grabados de la Successión de el rey $D$. Phelipe $V$ de Antonio de Ubilla, La batalla de Almansa, etc.) puede verse el reciente estudio de Ricardo Segura Simó [Segura, Pintura], centrado en el óleo que representa la batalla de Almansa.
}

«CUADERNOS DE ESTUDIOS GALLEGOS», Tomo XLIX, Fascículo 115, Santiago 2002. 
f) Madrid. Fundación Lázaro Galdiano $n^{\circ} 13539$ [Aguilar BAE-9 $\mathrm{n}^{\circ}$ 4991]. || Lisboa. Biblioteca del Palacio de Ajuda: 55-III-18/36 [CRS-BGP, s.n.].

Pormenorizada relación del desfile con el que la ciudad de Nápoles celebró la presencia del rey Felipe V, el sábado 20 de mayo de $1702^{32}$, que el áulico relator, pródigo en superlativos, refiere deslumbrado:

Día de anotarse en las historias más dichosas de aquel felicíssimo Reyno, y sólo digno de contarse con piedra blanca, como escrivirse con caracteres de estrellas en los anales de la eternidad. Festejávase mutuo el pueblo al tiempo de executarse su solemne ingresso en aquella gentilíssima metrópoli [...] el más glorioso y afortunado monarcha, don Felipe V, que viniendo desde la Esperia donde se oculta el Sol, sale como otro nuevo a llover diluvias de lucidíssimos rayos, y benigníssimas gracias sobre sus obsequiosíssimos vassallos [...] Rayó el alva felicíssima, y el Sol más de lo acostumbrado se dexó ver, radiante y resplandeciente, por obsequiar la inmortal gloria de el ínclito Monarcha que impera en el uno y otro mundo, a quien él, en su liminosa carrera, con su claríssima luz le dora. (h.1r).

El tono encomiástico de este prólogo se mantiene a lo largo de toda la relación, combinando los halagos hacia Felipe $\mathrm{V}$ con la descripción del aparato festivo y una cuidadosa ennumeración de los nobles y personas principales que participaron en la cabalgata, su función y sus galas. Si no resultase anacrónico, podría emparentarse esta relación con los más edulcorados reportajes del registro rosa de la prensa del corazón en los primeros años del siglo XXI: en un marco incomparable y con la complicidad de los astros, que colaboraron para realzar y proporcionar mayor brillantez al acto, tiene lugar un desfile celebrado en un clima de gene-

\footnotetext{
${ }^{32}$ Aunque la llegada de Felipe V a Nápoles se produjo el 17 de abril (vid. $\mathrm{n}^{\circ}$ 4), la entrada formal del Rey a la ciudad se postergó hasta el día 20 de mayo. Entretanto, el Monarca asistió a diversos actos organizados en su honor, entre ellos un concierto a cargo de Alejandro Scarlatti [Kamen, Felipe V: 33]; pudo, asimismo, presenciar la célebre licuación de la sangre de S.Genaro en la Catedral napolitana, interpretada como una buena señal para el nuevo rey. Mientras esto ocurría en Nápoles, concretamente el 15 de mayo, la Alianza de Inglaterra, Austria y las Provincias Unidas declaraban la guerra a Luis XIV, iniciándose así la Guerra de Sucesión. Una detallada descripción de la ceremonia de entrada de Felipe $\mathrm{V}$ en Nápoles y de las arquitecturas festivas que para tal ocasión se prepararon puede verse en Ubilla [Successión: 467-494].
} 
ralizada felicidad en el que destaca, por supuesto y por méritos propios, Felipe $\mathrm{V}$ rodeado por una pléyade de nobles, cortesanos y gentes principales de Nápoles, a cuyas vestiduras, joyas y corceles se dedica el grueso de la relación. Los criados y lacayos son sólo figurantes en una celebración que los necesita como elemento ornamental, parejo a la del «numeroso pueblo que desde las ventanas y calles admiraba tanta grandeza» (h.2r), aunque no quede muy claro si por la propia magestuosidad del acto o porque «el Real y General Tesorero Mayor de el Reyno [...] assistido sólo de sus porteros, con quatro grandes bolsas de terciopelo carmesí guarnecidas de galón de oro y llenas de cantidad de varias monedas de plata [...], las arrojava con larga mano al innumerable pueblo que, suspirando entre lo denso de la turba, aturdía el ayre entre el incansable repetir de ¡Viva, viva! y los aplausos que hazía a nuestro glorioso éroe Felipe V» (h.2r).

Como anexo a la relación se proporciona, a dos columnas, un «Indice de los títulos y cavalleros napolitanos y romanos y varones del Reyno que fueron en la función» (h.4r-v) que inventaría alfabéticamente los títulos de los príncipes, duques, marqueses, condes y caballeros que participaron en el desfile.

\section{6}

+ / RELACION VERDADERA, Y PUNTVAL, / que un Cortesano, hijo de la Coronada, y siempre / Real Villa de Madrid, haze a un amigo suyo, / refiriendo los sucessos, y triunfos con que hizo, y / celebró la Redencion la Celeste, Esclarecida, y / Real Religion de Nuestra Señora de la Merced, / este año de 1702. en la Ciudad de Argel, por las / Prouincias de Castilla, y Andalucia, desde la sa-/lida que hizieron desta Corte los Reuerendissi-/mos Padres Redentores, hasta su feliz entrada / en ella.

a) s.a $[1702]^{*} \|$ s.l. $\|$ s.i. $\|$ s.ed. || s.d.t.

b) $4^{\circ} \| 14 \mathrm{pp} .+1 \mathrm{~h}$ (en blanco) $\left\|\mathrm{A}-\mathrm{B}^{4}\right\|$ Cabecera: composición a línea tirada, con sangría francesa \| Inicial abierta de tres líneas sobre fondo con decoración vegetal || Reclamos (gran- / Ra- / Die- / pa- / las / ci / Estan- / mi- / pudo / que / cedes, / del / re- ).

c) Redención de cautivos $\|$ Castellano \| Prosa || Relación verdadera y puntual.

d) BUS: Public.Diario-48 (1700-1704), ubicado entre $G d M$ de 4 de julio de 1702 y $G d M$ de 11 de julio de 1702 .

e) BUS: RSE.Var.III-12 [Bustamante, $C B U-X V I I I \mathrm{n}^{\circ}$ 12254].

f) - 
Relación de la redención de cristianos cautivos en Argel realizada por los mercedarios de las provincias de Castilla y Andalucía durante los primeros meses de 1702 .

Se abre la relación refiriendo como el 9 de febrero de 1702, el Padre General de la Orden de la Merced hizo pública la intención de su congregación de llevar a cabo una nueva redención de cristianos cautivos en Argel, que dio comienzo cuatro días después con la salida, desde la iglesia de la Merced de Madrid y en dirección a Cádiz, de tres frailes mercedarios: Fr. Francisco Estevan Sotelo, Fr. Sebastián Agustín y Fr.Gaspar de San Agustín; a ellos se sumaron, en Cádiz, otros tantos frailes pertenecientes a la provincia de Andalucía: Fr. Bartolomé de Figueroa, Fr.Rafael de Ayala y Fr. Juan de la Ascensión. Juntos embarcaron en la tarde del 13 de abril, arribando al puerto de Argel tres días después.

El martes, 17 de abril de 1702, llegaron los mercedarios a «aquella ciudad bárbara, nefanda Sodoma, pyrata y escándalo de las almas de Dios [...], torpe y codiciosa» (p.3) provocando la alegría tanto de los cautivos como de sus raptores. Alegría generalizada pues, aunque por diferentes motivos: la de los primeros, porque la presencia de los frailes de la Merced reedificaba la esperanza de quienes no habían sido rescatados en anteriores redenciones (tres en los últimos ocho meses); la de los segundos, porque con el pago de los rescates «llegava la ocasión de saciar su infernal codicia» (p.3).

En pocos días de negociación rescataron los mercedarios a 482 esclavos cristianos (entre ellos tres frailes, un sacerdote y un importante número de oficiales y soldados), aun a fuerza de «muchos trabajos, baldones, afrentas y singulares tyranías contra el santo caudal de la santa Redención, obligándoles a rescatar en siete mil pesos sólo dos cautivos pobres, y muchíssimos por el precio de seiscientos y quinientos» (p.4); asimismo tuvieron ocasión de rescatar a dos cautivos cristianos que llevaban camino de la horca: Fr.Sebastián de San Agustín «arrojado a los pies obscenos y bárbaros del Governador [de Argel], le suplicó y pidió las vidas de aquellos pobres cautivos» (p.4), a lo que el Gobernador accedió conmovido por la acción del fraile.

Redentores y redimidos embarcaron el 6 de mayo hacia Mallorca, fondeando en el puerto de Palma dos días después, pero aún tendrían que pasar todos ellos dieciocho días de cuarentena antes de acceder a la ciudad, en la que entraron en procesión acompañados por las ordenes reli- 
giosas y «tan crecido número de gente que parecía se avía despoblado la ciudad, a no aver hallado el mismo concurso por las calles [...]. Con razón es llamada ciudad de las Palmas, pues lleva la palma a todas en honrar y favorecer» (p.5). Pareja fue la expectación y el entusiasmo que los redimidos y sus redentores despertaron en Alicante, a cuyo puerto arribaron, desde el de la Palma, el 9 de junio.

Diecisiete días empleó la comitiva en recorrer los caminos entre Alicante y Madrid: saliendo de la ciudad levantina el 10 de junio, llegaron a la Corte en la tarde del 27 del mismo mes, siendo recibidos «con tan general aplauso y con ansia tan christiana, que no huvo señor ni cavallero que no solicitasse ser el primero que llegasse a la huerta que llaman de Casani, para recibir en su coche a los redentores y redimidos [...], formando desde el campo hasta el Hospital General, y desde éste toda la hermosa quanto vistosa calle de Atocha, Plaça Mayor y calle de Toledo, tan numeroso quanto nunca vistoso concurso» (pp.8-9). En las puertas del convento de la Merced los recibió el Padre General que esperaba a los redimidos y a los redentores, a los que cuatro meses antes «expuso con ánimo generoso a la esclavitud y al cuchillo» (p.9) enviándolos a negociar con los argelinos.

La procesión general hubo de retrasarse hasta el regreso de la Reina a la Corte $^{33}$. Celebrada el primer día de junio, se describe, abundando en superlativos e hipérboles, en terminos semejantes a las de Palma y Alicante: los clarines, pífanos y cajas preceden a las filas de cautivos rescatados que marchan en pos del estandarte de la Orden; alrededor de la imagen de Nuestra Señora de las Mercedes «tan adereçada y ricamente vestida que el arte, el asseo y la riqueza fue la admiración de la Corte» (p.12), los miembros de la Orden de la Merced recibían «en premio de su trabajo, zelo y desvelo, los parabienes de todos por aver sacado de las tinieblas de la esclavitud a puerto de claridad tanto número de fieles» (p.12).

Al día siguiente, domingo, se celebró una misa en la que confesaron y comulgaron todos los rescatados, asistiendo al sermón pronunciado por Fr. Mateo Antonio de Tebar, predicador real. A continuación se celebró

${ }^{33}$ Se refiere el retorno de la Reina a la Corte en la Gaceta de Madrid del martes, 4 de julio de 1702 .

«CUADERNOS DE ESTUDIOS GALLEGOS», Tomo XLIX, Fascículo 115, Santiago 2002. 
una comida en el refectorio del convento mercedario servida, entre otros, por el Padre Maestro ${ }^{34}$ de la Orden. Terminada la comida, finaliza la relación: «Despidiéndose los redentores de sus amados redimidos, se partieron el siguiente día cada uno a su patria y casa para gozar la felicidad de su deseada libertad, que ruego a Dios se la conceda, libres de la esclavitud de la culpa y de las tinieblas y horror del pecado. Amen.» (p.14).

+ / FELIZ EMPRESA, / Y VICTORIOSO REENCVENTRO / DE LAS ARMAS DE LAS DOS NACIONES, / con los Imperiales, disputando la entrada del / Modenès en el día 26. de Julio / de 1702.

a) s.a. [1702]* || Madrid || Antonio Bizarrón || s.ed. || Colofón: «Con Privilegio. En Madrid: Por Antonio Bizarron»».

b) $4^{\circ}$ (corto de márgenes: $120 \times 189 \mathrm{~mm}$ ). || 2 hs. || s.sign. || Cabecera: composición epigráfica || Inicial simple de tres líneas $\|$ Reclamos (aquar- / de / dar-).

c) Militar: batalla \| Castellano \| Prosa \| s.form.

d) BUS: Public.Diario-48 (1700-1704), ubicado entre $G d M$ de 8 de agosto de 1702 y $G d M$ de 15 de agosto de 1702 .

e) -

f) Lisboa. Biblioteca del Palacio de Ajuda: 55-III-24/7 [CRS-BGP, s.n.] || París. Bibliotheque Nationale de France: OD-28, Tolbiac. [BNF n $\left.\mathrm{n}^{\circ} 33390404\right]$.

Relación de la batalla entablada en el lugar de Victoria ${ }^{35}$ entre las tropas imperiales del príncipe Eugenio y el ejército hispanofrancés que había salido de Cremona el día 20 con intención de tomar Casal Mayor. La defensa establecida por el príncipe Eugenio para asegurar la llegada de

\footnotetext{
${ }^{34}$ En el impreso figura sólo «Padre Maestro». Un cristus, a tinta, remite a una nota marginal manuscrita con letra de época en la que se lee: «General». Nos parece poco probable que esa precisión haya salido de la mano de un lector (un receptor tan puntilloso debería haber realizado otras muchas apostillas a lo largo de cada plana) y quizá se pueda atribuir a una corrección realizada en la misma imprenta.

${ }^{35}$ En Ubilla [Successión: 571-577], puede verse una minuciosa descripción de esta batalla ilustrada con un grabado calcográfico de 65 x $49 \mathrm{~cm}$., diseñado por Philippo Pallota, que representa la disposición de los ejércitos.
} 
víveres fue inútil: Felipe V llegó a Castel Novo, que halló desierto de habitantes pero repleto de provisiones; desde ese lugar salió en socorro del duque de Vendôme, entablándose una nueva batalla que finalizó con la fuga de los imperiales. Los esfuerzos por parte de los mandos del ejército imperial para recomponer sus tropas no dieron el fruto deseado, y la victoria, en la que participó Felipe $\mathrm{V}$ «espada en mano» (h.2r), fue rotunda: 700 muertos y 400 ahogados en el río y otros tantos prisioneros de las filas imperiales por sólo 120 bajas, entre muertos y heridos, en las tropas borbónicas. El resultado está claro: «Quedan las tropas de Su Magestad señores de aquel país» (h.2v).

Concluye la relación con la mención de los jefes y oficiales que más destacaron en la acción y, como falda, la noticia de un nuevo triunfo: la derrota infringida a 400 caballeros alemanes, en el campo de Ribalta, por las tropas aliadas al mando del príncipe de Baudemont.

La Gazeta de Madrid del martes 15 de agosto de 1702 (pp.129-130) refiere esta batalla en términos semejantes, incluida la magnificación de los éxitos propios llegando a descripciones hiperbólicas que contribuían a animar a los lectores y a reforzar su confianza en una victoria aún muy lejana. Así se narra como en esta batalla los imperiales, incapaces de resistir el empuje aliado del duque de Vendôme y el señor Albergoti, huían y se arrojaban al río Tasson: «donde fueron tantos los que cayeron y se ahogaron, que passaron veinte hombres de frente como cosa de ducientos passos sobre los hombres [ahogados del ejercito imperial] y sobre los cavallos sin mojarse los pies» (pp.129-130).

Entre los impresos que adquirimos en el mes de febrero de 2002 en la Librería Anticuaria hay una variante de esta edición (que denominaremos V) que difiere en el texto y en la composición de algunos párrafos respecto a la edición que aquí comentamos (y que denominaremos BUS). Tanto la cabecera como el texto de la h.1r son idénticas, al igual que el colofón y los reclamos, de manera que, aparentemente, parecen dos ejemplares del mismo impreso. Las diferencias que hemos localizado son las siguientes:

A.- h.1v, líneas 19-22. Reducción de la sangría de inicio de párrafo (de 8 a $5 \mathrm{~mm}$ ) en BUS que altera la composición de las líneas 19-22: 
BUS

$\ll^{19}$ Embió ... desertores / ${ }^{20}$ enemigos ... tres $/{ }^{2}$

${ }^{1}$ mil ... Darmestadt / ${ }^{22}$ y ... seguía»
$\mathrm{V}$

« ${ }^{19}$ Embió ... deserto- / ${ }^{20}$ res ... más / ${ }^{21}$ de ... Dar- /

${ }^{2}$ mestadt ... seguía».

B.- h.2r, líneas 26-27. Diferencias en el texto que suponen alteraciones en la composición de líneas del párrafo aunque no en la plana.

\section{BUS}

«... perdido los enemigos. De nuestra parte ha avido hasta ciento y veinte entre muertos y

heridos. De los alemanes ...»
V «... perdido los enemigos. Serán entre prisioneros y muertos hasta 100 de nuestra parte, y sólo un oficial prisionero. De los alemanes...».

C.- h.2v. El ejemplar de BUS añade, al final del tercer párrafo, la relación de los oficiales que más se destacaron en el combate y una nota acerca de las intenciones del ejercito borbónico de enfrentarse nuevamente a los enemigos, con la que se cierra la relación. El ejemplar $\mathrm{V}$ omite la relación de oficiales más destacados sustituyéndola por una ampliación de la información acerca de las intenciones del ejercito borbónico para los próximos días. Aunque la composición de la mitad inferior de la plana difiere de un ejemplar a otro (y la información se modifica) el número de líneas se mantiene constante: 35 en ambos ejemplares.

BUS (líneas 19-24)

«Sobresalió mucho el valor del señor duque de Bandoma, y de los señores tenientes generales, conde de Rebel, de Tessé, de Crequi, de Baubecourt, de Befonz, de Mongon, y de Marsey, y del sargento general Baltone, Chavini y Mauni. Y el esquadrón de Gen-Darmería, comandado por el señor de Mesieres, hizo maravillas»

BUS (líneas 34-35)

«El día 27 se encaminava el exército en busca de los enemigos».

\section{V (líneas 30-35)}

«Aún no está descubierta la intención del sitio formal de alguna plaza, aunque ay orden ya para el día 27 de julio, para que se adelanten las tropas a la puente que tienen los enemigos junto Mantua, porque en aquel campo está el mayor poder de sus armas, y según esto será el fin acometerlos en sus trincheras».

«CUADERNOS DE ESTUDIOS GALLEGOS», Tomo XLIX, Fascículo 115, Santiago 2002. 
Como se deduce de las últimas líneas, hay al menos tres días de diferencia en la redacción de ambos ejemplares, siendo el texto V («hay orden ya para el 27 de julio...») anterior al texto BUS («El día 27 se encaminava el exercito ...»).

Bajo éste mismo título, Aguilar Piñal [BAE-9 no 2901] menciona dos ejemplares de la Biblioteca Nacional de Madrid (signaturas: V.E.690 [76] y V.E.818 [33]); dado que no hemos podido verlos y por lo tanto no hemos podido comprobar si corresponden a BUS o a V, hemos optado por no incluirlos en el apartado $f$.

Acerca de esta batalla hay una relación sevillana titulada Feliz reencuentro de las dos naciones con los imperiales, disputando la entrada del Modenès en el día 26 de julio de 1702, 1702, Sevilla, s.i., $4^{\circ}, 2$ hs. [CCPB $\mathrm{n}^{\circ}$ 60837].

\section{8}

+ / COPIA DE CARTA/ ESCRITA DE MUNICH, / el dia 10. de Septiembre de 1702. / por Mons.N. à Mons.N.

a) s.a. [1702]* || Madrid || Antonio Bizarrón || s.ed. || Colofón: «CON PRIVILEGIO / < filete segmentado> / En Madrid: Por Antonio Bizarròn».

b) $4^{\circ}$ || 2 hs. || s.sign. || Cabecera: composición en base de lámpara || Inicial simple de dos líneas || Reclamos (for- / Con- / Prin).

c) Militar: asalto \| Castellano \|| Prosa \| Copia de carta.

d) BUS: Public.Diario-48 (1700-1704), ubicado entre $G d M$ de 17 de octubre de 1702 y Noticias extraordinarias ... de 17 de octubre de 1702.

e) BUS: RSE.Var.III-17 [Bustamante, $C B U-X V I I I \mathrm{n}^{\circ}$ 11785.- Aguilar $B A E-9 \mathrm{n}^{\circ} 1305$ (aunque: «escrita en Munich»)].

f) Madrid. RAH: 11/9391 n 636 [CCPB n ${ }^{\circ}$ 285310] \| París. Bibliotheque Nationale de France: M-(...), Tolbiac. [BNF $\mathrm{n}^{\circ}$ 33326959].

Relación de la toma de Ulma, capital de la Suevia, por las tropas de su Alteza Electa de Baviera al mando del señor Peckman, el 8 de septiembre de 1702 .

Comienza la relación explicando el motivo del asalto: Su Alteza Electoral de Baviera había sido invitado por los círculos de Franconia y Suevia 
a mantenerse al margen de la guerra, distanciándola de sus fronteras, pero los Círculos de Franconia y Suevia, mudando su decisión inicial, entraron en guerra en apoyo del Archiduque.

$\mathrm{Su}$ Alteza Electoral de Baviera, para forzar al Círculo de Suevia a apartarse de la guerra y proteger la frontera bávara, decidió asaltar su capital, Ulma, situada a orillas del Danubio. Para ello envió al lugarteniente general de sus guardias, el señor Pekman que, valiéndose de una estratagema, entró en la villa buscando los puntos más desprotegidos de sus defensas para realizar una ofensiva, y vistió a medio centenar de sus oficiales de paisanos, «a los más mozos de mugeres» (h.1v), que esconderían sus armas bajọ los aparejos propios de su condición: telas para vender, espuertas, corderos y aperos de labranza. Estos oficiales camuflados se introdujeron en la villa por la puerta de los Gansos, un portillo débilmente defendido que servía a las aldeas circundantes, al mismo tiempo que seiscientos dragones del regimiento del conde de Fels se emboscaban en una arboleda próxima dispuestos como punta de lanza para la toma de Ulma. A una señal convenida, los oficiales camuflados sorprendieron al cuerpo de guardia de la puerta de los Gansos y dieron paso a los dragones del conde de Fels; aunque la guarnición de la villa comenzó una contraofensiva apoyada por los burgueses organizados en escuadras «y hasta las mugeres de la villa corrieron como enfurecidas, tomando las armas que pudieron aver a las manos» (h.2r), la llegada de las tropas de retaguardia inclinó la balanza de la victoria a favor del ejército de Su Alteza Electoral.

Tomada la villa, se entregó una carta al Magistrado de la ciudad asegurando el respeto de los bienes y derechos de sus ciudadanos, y explicando que el motivo del asalto era proteger la frontera bávara y reducir a Franconia y Suevia «a los primeros principios de su associación, establecer la paz y la quietud pública apartando la guerra del Rhin en la qual no tiene ningún interés el Imperio y que, según la situación presente de la Europa, no podía traer más que la total ruina de las círculos» (h.2r)

Al ser informado del suceso, su Alteza Electoral envió a Ulma las tropas que campeaban en Lichtemberg y Rain y envió correos a los principales directores de los círculos de Franconia y Suevia para informarles de sus intenciones y «exortarlos se aparten de la guerra y reduzgan todas las cosas a los primeros términos y principios de la associación» (h.2v) añadiendo que «si $[\ldots]$ no se siguen estas fieles amonestaciones $[\ldots]$ toma- 
rá Su Alteza Electoral el partido como juzgare más conveniente para responder delante de Dios y de los hombres y como fuere más útil para el bien y conservación de sus estados y pueblos» (h.2v).

Finaliza la misiva confirmando el fallecimiento del señor Pekman, que fue herido al comienzo de la acción, «con gran sentimiento de Su Alteza Electoral por aver perdido en él un excelente oficial» (h.2v).

El redactor de la noticia de la toma de Ulma, fechada en «Straburgo» el 22 de septiembre de 1702 y publicada en la Gazeta de Madrid del martes 17 de octubre del mismo año, se limitó a resumir esta Copia de carta escrita de Munich transcribiendo literalmente algunos párrafos. En el mismo número de la Gazeta, y como noticia fechada en Viena el 12 de septiembre de 1702, se dice: «Ha causado gran sentimiento la sorpresa de Ulma por el duque de Baviera, por aver cortado los designios que se avían formado para las asistencias de Italia» (p.163).

\section{9}

+ / BREVE RELACION / DE LA VICTORIA, / QUE EL SEÑOR MARQUES / de Villars, Teniente General de los Exer-/citos del Rey Chistianissimo ha obteni-/do, despues de averse apoderado de la / pequeña Villa de Neuburg, en las vezin-/dades del Rhin, el dia 15. de Octubre / de 1702. contra las Armas Imperiales, / mandadas por el Señor Prin-/cipe Luis de Baden.

a) s.a. [1702]* || Madrid || Antonio Bizarrón || s.ed. || Colofón: «CON PRIVILEGIO / < filete segmentado> / En Madrid: Por Antonio Bizarron».

b) $4^{\circ} \| 2$ hs. || s.sign. || Cabecera: composición epigráfica || Inicial simple de tres líneas || Reclamos (Man- / La / deras).

c) Militar: batalla || Castellano || Prosa. || Breve relación.

d) BUS: Public.Diario-48 (1700-1704), ubicado entre $G d M$ de 24 de octubre de 1702 y $G d M$ de 7 de noviembre de 1702 .

e) BUS: RSE Var III-16 [Bustamante, $C B U-X V I I I \mathrm{n}^{\circ} 12243$ ].

f) Madrid. BN: V.E. 818 (58) [Aguilar $B A E-9 \mathrm{n}^{\circ}$ 506].

Relación de la batalla que entablo el marqués de Villars, teniente general del ejército hispanofrancés, contra las tropas imperiales al mando 
del príncipe Luis de Baden y que, a pesar de la inferioridad numérica, supuso un nuevo triunfo para las tropas borbónicas.

Después de la toma de Neoburgo en la noche del 12 al 13 de octubre por el ejercito hispanofrancés, el victorioso marqués de Villars fue informado de ciertos movimientos de las tropas imperiales con intención de recuperar la plaza. Para contrarrestar esta ofensiva, el Marqués propició un nuevo encuentro bélico en las proximidades del fuerte de Friedlingen $\mathrm{y}$, a pesar de la superioridad numérica del ejército imperial, la pericia y el arrojo dieron la victoria a las tropas de las dos Coronas.

La relación continúa destacando los méritos de los victoriosos combatientes: «para nombrar los que se han distinguido basta ver el orden de batalla» (h.2r) aunque, como es habitual en estos documentos, se menciona el nombre de los mandos: el señor de Villars, el señor de Dausiac, el señor de Masembal, el príncipe de Taranta, etc. Se cierra la descripción de la batalla refiriendo las bajas imperiales: más de 3.000 muertos, entre ellos el general Stausemburg y el conde de Fustemberg, prisioneros, y cuantiosas pérdidas materiales, que contrastan con las escasas bajas hispanofrancesas donde «no se ha perdido una bandera, estandarte ni timbal» (h.2v).

Como colofón, en letra cursiva y de cuerpo más pequeño se añade: «Estas noticias del campo de Feydeylinque, con fecha de 15 de octubre, las recibió la Reyna nuestra Señora con expresso de París el jueves 26, y se esperan las demás particularidades y los efectos favorables que se han de seguir a esta grande acción» (h.2v).

La narración de esta batalla, de sus preliminares y consecuencias, se recoge en términos semejantes en la Gazeta de Madrid del martes 31 de octubre de 1702, de manera que el texto de la Gaceta parece un resumen de la Breve relación.

10

+ / CLARA DEMONSTRACION, / de las operaciones de las dos Coronas, y vrebe / respuesta à los cargos de los Imperiales.

a) 1702 || Colonia || Pedro Nassau || s.ed. || Colofón: «CON LICENCIA DE LOS SUPERIORES. / < filete> / IMPRESSO EN COLONIA. AñO DE 1702. / POR PEDRO NASSAU».

«CUADERNOS DE ESTUDIOS GALLEGOS», Tomo XLIX, Fascículo 115, Santiago 2002. 
b) $4^{\circ}$ || VIII pp. || $\mathrm{A}^{4} \|$ Cabecera: composición a línea tirada, con sangría francesa || Inicial simple de tres líneas || Reclamos (de / y Olan/ sufrió / para / ami- / sobre / nera-).

c) Política: apología real || Castellano || Prosa || Clara demonstración.Breve respuesta

d) BUS: Public.Diario-48 (1700-1704), ubicada entre $G d M$ de 26 de diciembre de 1702 y 3 hojas en blanco correspondientes a las guardas posteriores del volumen de 1702 .

e) -

f) Sevilla. Universidad: 109-39 (13) [Aguilar $B A E-9 \mathrm{n}^{\circ}$ 1029] || Sevilla. Universidad: 112-28 (4) [Aguilar $B A E-9 \mathrm{n}^{\circ} 1029$ ] || Madrid. Fundación Lázaro Galdiano $\mathrm{n}^{\circ} 119620$ [Aguilar BAE-9 $\mathrm{n}^{\circ} 1029$ ] ॥

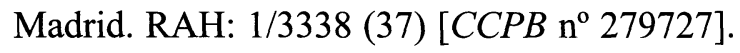

Respuesta al alegato «[que] han hechado los Imperiales por el mundo [en] varios papeles para fundar su derecho a la successión universal de España, en quienes se halla buen latín pero poca razón, palabras que alagan pero engaños que desbían» (p.I).

El relator pone de manifiesto el respeto que siente hacia la casa de Austria (aun sin aceptar sus métodos y sus aspiraciones), apoyándose en la devoción que sienten todos los españoles hacia la dinastía de los Habsburgo, a pesar de que «al principio costó mucho quererla» (p.II), refiriéndose, sin duda, a la fría acogida que Castilla dispensó al joven Carlos I y a su séquito flamenco. Reparados los agravios y errores cometidos por un rey demasiado joven y ajeno a los usos hispanos, y después de casi dos siglos de relación, el autor de esta Demonstración desea los mayores éxitos a la casa de Austria: «No ay español que no dessee al señor Emperador muchas victorias contra sus enemigos, pero no han de ser en perjuizio nuestro, que sobrados enemigos tiene para llenarse de trofeos» (p.I), aunque éstas victorias deberán buscarse en otro pagos, lejos de la Península Ibérica, y luchando contra los enemigos comunes que son los enemigos de la Cristiandad: «Y el señor Emperador sea tan dichoso que ponga sus águilas en Constantinopla, y vea en sus nietos reynos poderosos de la Asia, campo dilatado para sus conquistas.» (p.VIII).

Por lo que se desprende de este opúsculo, las alegaciones imperiales reclamando el trono español se asentaban en un heterogéneo abanico de 
motivos: el afecto de los españoles hacia los Habsburgo, el opuesto carácter de españoles y franceses que haría inviable la convivencia bajo una corona común, los antiguos derechos hereditarios favorables a los austríacos, las peligrosas aspiraciones francesas a una Monarquía Universal, la incompatibilidad de la sucesión al trono francés y al español, la amenaza de excomunión pontificia, etc. El anónimo autor de esta Demonstración refuta, una por una, las alegaciones imperiales utilizándolas para reivindicar al duque de Anjou como heredero natural del Carlos II; así, a la referencia al cariño que los españoles sienten hacia los Austrias, responde el relator que este sentimiento es evidente puesto que «el señor Philipo Quinto es austríaco, y en él se renueban todas las estimaciones a esta gran Casa» (p.I); ante los «derechos sucesorios antiguos» alegados por los imperiales, contesta el relator que «el señor Carlos Segundo consultó esta herencia con universidades, prelados, jurisconsultos y otros hombres de letras y virtud, y aprobaron su resolución y, sobre todo, lo dexó assí dispuesto» (p.II); etc.

A lo largo del texto se aprecia un tono laudatorio hacia Felipe $V$ que se pone abiertamente de manifiesto en las líneas finales:

Nuestro rey es Felipe V [...] el que ha sabido merecer todo lo que ha llegado a heredar. Este vino de la mano de Dios por tan singulares caminos: príncipe que con sus amables prendas hechiza los corazones, gallardo, valiente, discreto, silencioso y amigo de la verdad [...]. Mientras los señores austriacos han sido nuestros dueños se les ha obedecido con fidelidad y se les ha amado con ternura, aora se les desea mucha felicidad; pero déxennos amar a nuestro Rey, que ya $<$ ha $>$ jurado se ha de defender aunque su grande abuelo le hiziera la guerra. (p.VII).

Otras ediciones de esta relación:

1. Sevilla, Francisco de Garay, 1701, $4^{\circ}, 2$ hs. [Aguilar Piñal, BAE-9 $\mathrm{n}^{\circ}$ 1028].

2. Barcelona, Francisco Guasch, 1702, $8^{\circ}, 7$ pp. [Pérez Picazo, Publicistica: $333 \mathrm{n}^{\circ}$ LX].

3. Cádiz, Cristóbal de Requena, $1702,4^{\circ}, 4$ hs. [Aguilar Piñal, BAE-9 $\left.\mathrm{n}^{\circ} 1030\right]$.

4. s.l., s.i., s.a., $4^{\circ}, 8$ pp. [CCPB $\left.\mathrm{n}^{\circ} 279726\right]$. 
11

LUIS XIV de Francia, rey Christianísimo.

+ / COPIA DE LA CARTA DE EL / Rey Christianissimo a nuestro Santo Padre Cle-/mente Vndezimo, tocante a los motivos de la guer-/ ra de Saboya.

a) s.a. [1704]* || s.l. || s.i. || s.ed. || s.d.t.

b) $4^{\circ} \| 12 \mathrm{pp}$. $\left\|\mathrm{A}^{6}\right\|$ Cabecera: composición a línea tirada, con sangría francesa || Inicial simple de tres líneas || Reclamos (ri- / Sus / que / la / dría / pe- / ta- / dor / tu- / jas / las).

c) Política: relaciones internacionales || Castellano \| Prosa \| Copia de la carta.

d) BUS: Public.Diario-48 (1700-1704), entre $G d M$ de 1 de abril de 1704 y $G d M$ de 8 de abril 1704.

e) BUS: Foll. 211-2. [Bustamante, $C B U-X V I I I \mathrm{n}^{0}$ 329] $\|$ BUS: Foll. 305-6. [Bustamante, $\left.C B U-X V I I I \mathrm{n}^{\circ} 330\right]^{36}$.

f) Madrid. Real Academia de Ciencias Morales y Políticas. 20605 (15) [CCPB $\mathrm{n}^{\circ}$ 310172] || Madrid. RAH: 2/2398 [CCPB $\mathrm{n}^{\circ}$ 309105]. $\|$ Madrid. RAE 39-X-9 (7) [CCPB n ${ }^{\circ}$ 321952: atribuye la autoría de este impreso a Felipe V].

Edición de la carta enviada por Luis XIV a Clemente XI, fechada en Versalles el 13 de enero de 1704, en la que el monarca francés expone al Pontífice los motivos que han provocado la guerra contra Saboya, que se sumó a la causa imperial el 8 de noviembre de 1703 a pesar de ser la reina de España hija del duque Víctor Amadeo de Saboya.

Luis XIV comienza su carta explicando que la ruptura de relaciones y el abierto enfrentamiento con Saboya no debe achacarse a un afán expansionista de la corona francesa; al contrario, declara que su pretensión desde el tratado de Ryswick fue conservar el reposo y la tranquilidad en Europa y «pareciome prevenirla con el tratado de la partición; en ésta negociación tuve muy presentes los interesses del duque de Saboya [...], quería con toda sinceridad contribuir a su engrandecimiento, si aquellos mismos a quienes después ha mirado como a sus más fieles

${ }^{36}$ Uno de los ejemplares de este impreso, catalogado por Bustamante en 1956 [Bustamante, $C B U-X V I I I \mathrm{n}^{\circ}$ 11788], ha desaparecido de los fondos de la BUS.

«CUADERNOS DE ESTUDIOS GALLEGOS», Tomo XLIX, Fascículo 115, Santiago 2002. 
amigos no se huvieran opuesto a las proposiciones que hize en su favor» (pp.1-2).

A lo largo de la carta, Luis XIV da cuenta de sus relaciones con el duque de Saboya, permanentemente oscilantes entre el acuerdo y el enfrentamiento debido al irregular cumplimiento de los tratados por parte de Víctor Amadeo de Saboya. Luis XIV salvaguarda su papel en estas quebradizas relaciones asegurando que siempre trató de colaborar con el Duque, como puso de manifiesto vinculando las coronas de Francia y de Saboya al casar a su nieto -y sucesor legítimo de Carlos II-, con María Luisa de Saboya. A pesar de todo, y de los acuerdos que firmaron los representantes de Francia y Saboya, Víctor Amadeo traicionó una y otra vez la confianza que sobre él depositaron tanto el rey francés como su nieto y sucesor de la corona de España; tampoco a los aliados, partidarios del pretendiente austríaco, les ofrecía demasiada seguridad el habitual comportamiento de Víctor Amadeo y desconfiaban «assí en Londres como en Viena [...] de su facilidad en romper los tratados» (p.5).

Tanto lo que se insinúa como lo que se afirma en esta carta acerca del carácter, los modos y la fidelidad a la palabra dada del duque Víctor Amadeo de Saboya compone un retrato que no sólo explica la ruptura de relaciones con la alianza hispanofrancesa sino la consideración que el Duque les merece a los imperiales, sus nuevos aliados: «iLa princesa de Dinamarca se ha gloriado, en la arenga que hizo al Parlamento de Inglaterra, de aver enlazado al duque de Saboya en los intereses de la Liga?» (p.11). La respuesta negativa a esta interrogación retórica sirve al autor de la carta para poner en entredicho al duque de Saboya e, indirectamente, como vehículo propagandístico contra de la Liga favorable al pretendiente austríaco.

La diferente signatura tipográfica $\left(\mathrm{A}^{4}-\mathrm{B}^{2}\right)$ del ejemplar existente en la Biblioteca del Palacio de Ajuda de Lisboa [CRS-BGP, s.n.] parece indicar una edición diferente, a pesar de los coincidencia del resto de los datos proporcionados por sus catalogadores. 
ASENSIO DE VICUÑA, Diego

+ / COPIA DE CARTA DEL ALMIRANTE / Don Diego Assensio de Vicuña, Cabo de los Galeones / que salieron de los Passages, con la noticia de su Na-/vegacion.

a) s.a. $[1704]^{*} \|$ s.l. $\|$ s.i. $\|$ s.ed. $\|$ s.dt.

b) $4^{\circ} \| 8$ pp. $\left\|\mathrm{A}^{4}\right\|$ Cabecera: composición a línea tirada, con sangría francesa || Inicial simple de tres líneas || Reclamos (El / cion / mu/ nue- / ner / dis- / pues).

c) Militar: batalla naval || Castellano || Prosa || Copia de carta.

d) BUS: Public. Diario-48, vol. 1700-1704, ubicada entre $G d M$ de 22 de abril de 1704 y $G d M$ de 29 de abril de 1704).

e) -

f) Madrid. Universidad Pontificia de Comillas. XVIII-8328 (34) [CCPB $\mathrm{n}^{\circ}$ 193316] || Madrid. Museo Naval: BMN-4968 [CCPB ${ }^{\circ}$ 193316]. || Madrid. Museo Naval: IMP-C 1/35 [CCPB no 193316]. || Madrid. RAE: 14/8692 (6) [CCPB n 193316].

Relación de la batalla naval desarrollada el 22 de marzo de 1704 a la altura del Cabo de San Vicente, como consecuencia del ataque de una escuadra anglo-holandesa, bajo el mando del almirante sir George Rooke, a dos galeones españoles que, a las órdenes del almirante don Diego Asensio de Vicuña, navegaban desde el puerto de Pasajes hacia Cádiz. La relación transcribe (aparentemente) dos cartas enviada por don Diego a sus superiores.

La primera carta (p.1) está fechada a las once de la mañana del 22 de marzo de 1704 en el galeón Nuestra Señora de Portaceli, a treinta y ocho leguas al sur del Cabo de San Vicente, y firmada por el Almirante y otros oficiales. Refiere como al declinar el día anterior se avistaron nueve velas en el horizonte sin poder reconocerse su bandera ni su porte debido a la falta de luz; a la mañana siguiente y previendo que se tratase de naves enemigas, aunque las velas habían desaparecido de la vista, se convocó una reunión de la oficialidad de ambos galeones en la que se decidió una aproximación a la costa de Berbería para, al amparo de la noche, tomar los puertos de Cádiz o Gibraltar.

La segunda carta (pp.2-8), dirigida a don Domingo López Calo por don Diego Asensio de Vicuña, está fechada el 7 de abril de 1704 a bordo 
del navío inglés Sufolk, anclado en la ría de Lisboa; se trata de una información pormenorizada de los antecedentes, el combate y sus consecuencias, relatada por el máximo responsable de los galeones españoles desde su confinamiento en el Sufolk. Refiere don Diego la navegación desde la salida del puerto de Pasajes, dificultada por los estragos causados por los temporales del Atlántico en las arboladuras de ambos galeones, daños que repercutirían negativamente en su capacidad de maniobra frente a la escuadra anglo-holandesa, avistada por primera vez el 21 de marzo (como se recoge en la primera carta). A mediodía del 22 de marzo se desató un fuerte temporal que obligó a modificar el rumbo a ambos galeones, ocasionándoles graves desperfectos; aprovechando esta situación se produjo el ataque enemigo: una nave holandesa de cuarenta y seis cañones, y cinco navíos ingleses (de los doce que componían la escuadra enemiga), entablaron combate contra los dos maltrechos galeones, que ofrecieron resistencia durante siete horas hasta que el Santa Teresa, desarbolado, con graves daños en el casco y sin gobierno, tuvo que rendirse. Entre la mayor parte de la tripulación del Nuestra Señora de Portoceli, sin velas y sin mastelero, cundió el desánimo, y pidieron a Asensio que se rindiera; éste hizo reconocer las bodegas y, a la vista de que no había peligro de hundirse, trató de animar a la tripulación para que prosiguiesen combatiendo aunque, en vista de que «no surtía ningún efecto este medio [las palabras], recurrí al del castigo, descalabrando al más inmediato» (p.6). El almirante, dispuesto a sofocar el amotinamiento de la tripulación, abocó un cañón a la bodega «y luego me abançó la muchedumbre por detrás y me llevaron a la cámara, haziéndome el cargo de que por qué los quería bolar estando indefensos y aviéndome assistido hasta que huvo alguna esperança de poder salvar» (p.6). Aprovechando la confusión provocada por esta rebelión, los enemigos abordaron el Nuestra Señora de Portoceli, hicieron prisionero a Asensio y a los oficiales, y los pasaron al Sufolk, donde estaban también prisioneros el capitán Arreyzaga y el resto de oficiales del Santa Teresa.

El sábado 5 de abril arribó la escuadra a la ría de Lisboa, en la que se hundió el Santa Teresa, pereciendo doscientos de sus tripulantes. Como tanto el embajador de Francia como el cónsul de España habían abandonado la corte portuguesa, Asensio tuvo que recurrir al cónsul francés en Lisboa para enviar ésta información

Concluye la información: 
Estas son todas las circunstancias que han precedido en este desgraciado sucesso, que se servirá Vuestra Señoría poner en la noticia del Consejo para que, informándose de la verdad, se digne de executar conmigo lo que juzgare [...], siendo cierto que en ella, por la bondad de Dios, me hallo sin el más leve escrúpulo de aver executado todo aquello que mi cortedad tuvo por lo más conveniente, tanto para el mayor resguardo de los dos galeones en el viaje, como después, en el combate, para el mayor crédito de las armas de Su Magestad [...] De la Ría de Lisboa, a bordo del navío Sufolk, a 7 de abril de 1704 años. (pp.7-8).

Esta excusatio por la pérdida de los dos galeones fue atendida y entendida por el Felipe V y su Consejo que, según se recoge en la Gaceta de Madrid del 29 de abril de 1704 (p.72), nombraron a don Diego Asensio: "Almirante General, con la primera encomienda que vacare y dos mil doblones de ayuda de costa para asistir a la gente», en reconocimiento del valor que demostró en este combate. En la misma noticia de la Gaceta se recoge una referencia a este impreso: «Premiar el valor con que llenó [sic] toda su obligación don Diego Assensio de Vicuña en la refriega que tuvo con la esquadra de los enemigos (cuya puntual Relación, como también la noticia de averse ido a pique en la Barra de Lisboa uno de los dos baxeles con toda la carga y la gente enemiga que passó a él, anda impressa en carta suya escrita al Consejo)» (p.72). El redactor de éste suelto reescribe lo escrito por don Diego, que no es más que $s u$ interpretación de los hechos, de forma que el lector de la Gaceta recibe una información de cuarta mano ( $1^{\mathrm{a}}$. lo que ocurre. $2^{\mathrm{a}}$ lo que percibe don Diego. $3^{\mathrm{a}}$ Lo que escribe don Diego. $4^{\mathrm{a}}$ La síntesis que hace el redactor del suelto), despojada de la información sustancial, la pérdida de dos barcos, para centrarse en lo accesorio, el hundimiento del Santa Teresa con la carga y los enemigos que pasaron al galeón. El propio don Diego omite una cuantificación de las propias pérdidas humanas y materiales subrayando que, al llegar al Sufolk, pudo comprobar los importantes destrozos que había sufrido la nave enemiga y que, supone, se pueden hacer extensivos al resto de la escuadra anglo-holandesa.

En la Bibliotheque Nationale de France se conserva un ejemplar de este impreso con el colofón «Madrid. Por Antonio Bizarrón. 1704» $[B N F$ $\left.\mathrm{n}^{\circ} 30033179\right]$.

«CUADERNOS DE ESTUDIOS GALLEGOS», Tomo XLIX, Fascículo 115, Santiago 2002. 
Español Profesor de Minerva, $\mathbf{E l}^{37}$

+ / RESPVESTA BREVE, / AL MANIFIESTO, EN QVE EL REY / Don Pedro Segundo de Portugal, pretextò / los motivos que tuvo para romper la guerra / à las dos Coronas. / ESCRIVIOLA / EL ESPAÑOL PROFESSOR / de Minerva.

a) s.a. $[1704]^{*} \|$ s.l. || s.i. \| s.ed. || s.d.t.

b) $4^{\circ} \| 16 \mathrm{pp}$. || $\mathrm{A}^{8} \|$ Cabecera: composición epigráfica || Inicial simple de tres líneas || Reclamos (Ma- / Note / tex- / Dios, / Inge- / que / po- / Ma- / ro- / van / ca- / de / la / in-).

c) Política: motivos para la guerra || Castellano || Prosa || Respuesta breve.

d) BUS: Public.Diario-48 (1700-1704), ubicada entre $G d M$ de 14 de junio de 1704 y $G d M$ de 17 de junio de1704.

e) -

f) Madrid. Museo Naval: CF-161 (6) [CCPB $\mathrm{n}^{\circ}$ 310092] || Madrid. Real Academia de Ciencias Morales y Políticas: 20605 (13) [CCPB $\mathrm{n}^{\circ}$ 310092].

Larga carta, fechada el 14 de junio de 1703, que sirve a su autor para responder, en veintiún apartados, al manifiesto en que Pedro II de Portugal explicaba las causas que lo movieron a declarar la guerra a la alianza hispanofrancesa.

La datación de este impreso plantea un problema: es frecuente que en las relaciones de sucesos no se explicite el año de impresión, pero generalmente esa fecha coincide con la de los hechos narrados (lo que, en el legajo que nos ocupa, suele ratificar la perfecta ubicación de la relaciones entre las correspondientes Gacetas); en el caso de cartas, la data puede servir como orientación respecto al año de impresión. Esta Respuesta breve es una excepción: la carta está fechada el 14 de junio de 1703 pero, en el ejemplar que manejamos, se corrigió la fecha a tinta, manuscribiendo un

\footnotetext{
${ }^{37}$ No hemos podido averiguar a quién corresponde el seudónimo «El español professor de Minerva», aunque sí localizamos la referencia bibliográfica de un folleto de 2 hs. en $4^{\circ}$, fechado en Granada en 1704, de (aparentemente) la misma autoría: El reynante Belerophon Hyspano contra la enemiga chimera. Respuesta de un español proffesor de Minerva a Monsieur N., académico parisiense. [López-Huertas, Imp.granadinos $\mathrm{n}^{\circ} 1265$ ].
} 
4 sobre el 3, y se encuadernó entre las gacetas del 14 y el 17 de junio de 1704. Ni el texto de la Respuesta breve ni el contexto histórico arrojan luz alguna para datar esta carta, al contrario, aumentan la confusión: el 16 de mayo de 1703 el rey Pedro II de Portugal, rompiendo la neutralidad que hasta entonces había mantenido en la cuestión sucesoria, cede a las presiones imperiales y se une a la Gran Alianza mediante la firma del tratado de Methuen; esta Respuesta breve podría ser la réplica de los partidarios de Felipe $\mathrm{V}$ a la adscripción de Portugal a las fuerzas enemigas. Hasta aquí la datación parece sencilla: en 1703, una quincena después de la defección portuguesa, se publica esta Respuesta a los motivos alegados por Pedro II para tomar partido por el archiduque $\operatorname{Carlos}^{38}$. ¿A qué se debe la rectificación manuscrita de la fecha de la Respuesta y su perfecta ubicación en el volumen correspondiente a 1704 (entre la Gaceta del 14 y la del 17 de junio)? Aunque arriesgada, cabe una explicación que desde ahora mismo aceptamos como refutable (pero también posible): el 6 de mayo de 1704 el archiduque Carlos de Austria desembarca en Lisboa para hacer valer sus derechos a la corona española; casi al mismo tiempo Felipe $\mathrm{V}$ y el duque de Berwick salen de Madrid al frente de 24.000 hombres para tomar Lisboa y acabar con la amenaza militar que, desde Portugal, se cernía sobre el Reino. Es posible que las primeras acciones bélicas en la Península, que tienen lugar en Extremadura, y el carácter de guerra civil que comenzaba a tomar el conflicto, provocaran la puesta en circulación de los ejemplares sobrantes de la Respuesta breve (actualizándolos mediante el sencillo sistema de manuscribir a tinta un 4 sobre el 3 de la fecha original) o de una segunda edición de la misma para refrescar la memoria (y orientar la elección) de los españoles que se verían pronto abocados a tomar partido por Felipe V o por Carlos III. El valor propagandístico de esta Respuesta breve nos parece perfectamente válido para la situación peninsular de la primavera de 1704 .

Comienza la carta con una excusa retórica: alguien, a quien el autor se dirige como «Señor mío», sin más especificaciones, le ha pedido su opinión acerca de las explicaciones dadas por el Rey de Portugal para declarar la guerra. Es la excusa ideal para extractar párrafos de la carta del

${ }^{38}$ Aguilar Piñal [BAE-9 no 5991] fecha esta Respuesta breve en 1703.

«CUADERNOS DE ESTUDIOS GALLEGOS», Tomo XLIX, Fascículo 115, Santiago 2002. 
monarca portugués $\mathrm{y}$, apostillándolos, negar toda validez moral a la declaración de guerra y poner en tela de juicio tanto el comportamiento de Pedro II como, incluso, su amor por Portugal: «1. Señor mío. Vuestra Merced me manda en la de este correo le refiera y diga lo que me parece en las expressiones con que se ha manifestado al teatro del mundo el rey don Pedro de Portugal, queriendo hazer justificados los motivos que tuvo para romper la guerra a las Dos Coronas y tomar el partido chimérico de la Grande Aliança» (p.1). A continuación la consabida captatio benevolentiae del autor, manifestando que escribe sin ser «magistrado ni hombre de público empleo en la República» (p.1), guiado sólo por su amor a Felipe V y la obediencia que le debe al destinatario de la carta, y el ánimo «con que essa Tertulia ha dado en fomentar mis discursos, sin tener de buenos más que el único y especioso adorno de sus favores» (p.1).

A partir de aquí, y a lo largo de 20 apartados, el relator entresaca y apostilla párrafos de la carta de Pedro II para criticar al rey portugués. La primera alegación es de tipo formal: se basa en que Pedro II antepone en el orden de cita a los nobles e incluso al estado llano, posponiendo a los eclesiásticos que, como representantes de Dios en la tierra, deberían mencionarse en primer lugar. Otra critica le merece los motivos de la declaración de guerra a España:

Con aparente hipocresía prosigue diziendo 'Que Dios [...] es testigo de que no es ni ha sido su intención añadir nuevos reynos y provincias a su corona, y que ni la codicia ni la vanagloria han movido su inclinación' [...]. No puede caber en humano atrevimiento traer a Dios por testigo de un hecho cuya verdad no sea tan íntegramente indisputable [...] pues además de la margen septentional de el Río de la Plata [que] ha capitulado con el archiduque Carlos, se le han de ceder en perpetuidad a Portugal la ciudad de Badajoz, las plaças de Alcántara, Alburquerque y Valencia de Estremadura, y a Bayona, Vigo, Tuy y La Guardia en Galicia (p.4).

Punto por punto, el Profesor de Minerva refuta las aseveraciones del monarca luso contenidas en lo que comentarista entiende no es más que un «papelón». Así, donde el rey portugués aprecia sometimiento de España al poder naval francés: "Que las vanderas de la Armada Real de España se mandaron ceder en sus mares a las de Francia», en palabras de Pedro II, responde el relator «Si dixera que la Armada eran las galeras, y que a quien cedieron fue al Almirante General de la Armada Real de España, que lo era el conde de Etrè [...] dixera la verdad, pero ¿con 
qué se avía de llenar el papelón si no se valiera el autor [Pedro II] de supuestos de esta calidad?» (p.10). Poniendo en duda tanto la veracidad de las manifestaciones del monarca lusitano, como su capacidad intelectual (que hace extensivos a todos los portugueses), el Profesor de Minerva sube el tono descalificador en algunas respuestas y llega a insultar tanto a los naturales del vecino país como a sus aliados imperiales: «¿Y esto quién lo podrá dudar? (que no sea un entendimiento portugués o la barbaridad de un alemán)» (p.5), y calificando de «arrogancia portuguesa» (p.14) las aseveraciones de Pedro II acerca del embelesamiento de las promesas francesas. El relator se crece a lo largo de la Respuesta y se atreve a augurar «una tempestad de victorias [de Felipe V] cuyos tropheos hagan morir de embidia a las mismas cenizas de Alexandro» (p.14).

Amalio Huarte y Echenique, en el Suplemento bibliográfico a los «Papeles festivos del reinado de Felipe V» cataloga un ejemplar con el mismo título, en $4^{\circ}$ y de 16 pp., cuyo contenido resume: «Son consideraciones histórico-políticas acerca del manifiesto: su autor reconoce el derecho de Felipe V a ocupar la corona de España» [Huarte, Papeles: 386].

14

TOULOUSE. Luis de Borbón, conde de

+ / RELACION, / QUE EL SERENISSIMO SEÑOR / CONDE / DE TOLOSA / REMITIÒ AL REY N. SEÑOR, / REFIRIENDO CON INDIVIDUALIDAD / LO OCVRRIDO EN LA BATALLA, / QUE LA ARMADA DE SU MANDO / DIÒ A LA DE LOS ENEMIGOS / EL DIA VEINTE Y QUATRO DE AGOSTO / DE MIL SETECIENTOS Y QVATRO.

a) s.a. [1704]* || s.l. || s.i. || s.ed. || s.d.t.

b) $4^{\circ} \| 4$ hs. || s.sign. || Portada independiente con vuelto en blanco: composición epigráfica y, en su pie, festón de hojas de acanto \| Inicial simple de tres líneas, con orla entre doble marco de filetes y cabezas de clavo en las enjutas || Reclamos (va / go / no / ellos).

c) Militar: batalla naval || Castellano || Prosa || Relación.

d) BUS: Public.Diario-48 (1700-1704), ubicada entre $G d M$ de 2 de septiembre de 1704 y $G d M$ de 9 de septiembre de1704. 
e) -

f) Madrid. Universidad Pontificia de Comillas: XVIII-8328 (6). $\left[C C P B \mathrm{n}^{\circ} 193293\right] \|$ Madrid. Real Academia de Ciencias Morales y Políticas: 20605 (19). [CCPB no 193293] || Madrid. RAE: 14/ 8692 (7) [CCPB n $\left.{ }^{\circ} 193293\right]$.

Relación que el conde de Toulouse remite a Felipe $\mathrm{V}$ para informarle de la batalla naval librada entre la armada hispano francesa, al mando del relator, y la aliada, a las órdenes del almirante Rooke, que tuvo lugar el día 24 de agosto de 1704 frente a la costa de Málaga.

Refiere el Conde como al mediodía del 22 de agosto, hallándose la armada hispanofrancesa en la costa de Vélez Málaga para hacer aguada, dieron aviso las fragatas de guardia de que se aproximaba la escuadra enemiga, por lo que comenzaron los preparativos para el combate y la toma de posiciones de batalla de los navíos, operación que se demoró debido al escaso viento. $\mathrm{Al}$ amanecer del día 24 se avistaron ambos ejércitos a unas tres leguas de distancia.

La batalla comenzó a las diez de la mañana: la vanguardia hispanofrancesa del marqués de Villete trató de desordenar las líneas enemigas interponiéndose entre la vanguardia y el cuerpo de batalla aliados, intentando dejar a la escuadra de Schovel entre dos fuegos; viéndolo, el almirante Rooke hizo señal de empezar el combate. A partir de este momento el conde de Toulouse se limita a referir lo que ocurrió en su línea, ya que la violencia del combate, el fuego y el humo, impedían ver lo que ocurría en otras posiciones.

La narración del conde de Toulouse, aun sin ser triunfalista ${ }^{39}$, manifiesta su subjetividad: algunos navíos enemigos se hunden mientras que los de la armada hispanofrancesa sólo han de retirarse de la línea para ser reparados; la fuerzas no están equilibradas sino que favorecen al enemigo, tanto en cantidad como en armamento, y los combates individuales reflejan esta disparidad de fuerzas: «Monsieur de Rochallard, el mayor que peleó con su navío de sesenta cañones contra el de Schovvel, que tenía uno de noventa» (h.3r); incluso, según el relator, el viento era favo-

${ }^{39}$ No podía serlo dados los resultados finales de la batalla. Quizá por eso evita en todo momento utilizar términos como triunfo o victoria. 
rable al enemigo ${ }^{40}$. El combate duró aproximadamente cinco horas en vanguardia, aunque la retaguardia aliada seguía cañoneando al llegar la noche ${ }^{41}$.

Finalizada la narración de la batalla, de incierto resultado ${ }^{42}$, comienza el balance del encuentro: el comportamiento de los combatientes se califica de ejemplar y, aunque el número de bajas ha sido elevado, los oficiales muertos o heridos fueron sabiamente sustituidos por otros oficiales: «Monsieur de Relingieux [...] perdió una pierna, y monsieur de Rocalard, el cadete que por este accidente se hallava comandante de su baxel, se mantuvo muy bien en su puesto y hizo un gran fuego tan a tiempo que no echamos [de] menos la falta de monsieur de Relingieux» (h.4r).

Continúa el relator explicando como en la mañana del día 25 ambas armadas, distanciadas aproximadamente una legua, se dirigieron a la costa para recomponerse; ese mismo día y los siguientes tuvo la armada enemiga ocasión de reanudar el combate pero, a pesar de su superioridad numérica, optó por derrotar hacia las costas de Berbería, rehuyendo el enfrentamiento y dirigiéndose quizá (aventura el Conde de Toulouse) en dirección al Estrecho, con lo que queda la armada hispanofrancesa como dueña del campo de batalla a pesar de las evidentes ventajas de que disponían los aliados antes de comenzar la batalla.

Otra edición de esta Relación se imprimió en Sevilla, por los Herederos de Tomás López de Haro, en 1704 (4º 8 pp.) [Aguilar, BAE-9 n 5480 ].

\footnotetext{
${ }^{40}$ El marqués de San Felipe reduce la importancia que en esta relación se atribuye al viento como factor favorable a los ingleses, puesto que resultaba propicio para la estrategia del conde de Toulouse: «Trabajaron mucho los pilotos en mantener la línea, y mucho más los ingleses, porque el mismo favor del viento los echaba sobre la de los enemigos, y como era esto lo que el conde de Tolosa deseaba para llegar a las armas blancas, se mantenía a la capa» [Bacallar, Comentarios: 75].

${ }^{41}$ Las trece horas que duró el combate hicieron reconocer al almirante sir George Rooke que aquel había sido «el día de servicio más duro que jamás haya visto» [ $c f$. Kamen, FelipeV: 56-57].

${ }^{42}$ No podía el relator ofrecer un resultado de la batalla, puesto que las bajas y los daños eran semejantes en ambas flotas. El marqués de San Felipe declina la posibilidad de apuntar un vencedor cuando escribe: «Muchas cuestiones se levantaron sobre esta indecisa victoria, y ni aun leyendo lo que se escribió sobre esto nos atrevemos a definirlo.» [Bacallar, Comentarios: 75].
}

«CUADERNOS DE ESTUDIOS GALLEGOS», Tomo XLIX, Fascículo 115, Santiago 2002. 
+ / PRONOSTICO, SACADO DE LOS REYES DE PORTVGAL, PARA QVE / quien le lea ò oyga, haga el juyzio que se inferirà de los sucessos passados para / los presentes.

a) s.a. $\|$ s.l. $\|$ s.i. $\|$ s.ed. || s.d.t.

b) $4^{\circ} \| 2$ hs. $\left\|\mathrm{A}^{2}\right\|$ Cabecera: composición a línea tirada con sangría francesa || Inicial simple de dos líneas || Reclamos (Al- / Qué / me) || A partir de la línea 28 de la h.1v. se reduce el tamaño del cuerpo de letra.

c) Política: apología de Felipe V || Castellano || Prosa || Pronóstico.

d) BUS: Public.Diario-48 (1700-1704), ubicada entre $G d M$ de 23 de septiembre de 1704 y $G d M$ de 30 de septiembre de1704.

e) -

f) Madrid. Universidad Pontificia de Comillas: XVIII-8328 (32). [CCPB $\mathrm{n}^{\circ}$ 193315] || Madrid. RAH: 1/3338 n 33 [CCPB $\left.\mathrm{n}^{\circ} 193315\right]$ || París. Bibliothèque Nationale de France: OD-88, Tolbiac. [BNF $\left.\mathrm{n}^{\circ} 33555800\right]$.

Pronóstico realizado a base de hilvanar episodios de la historia de Portugal que sirven al relator para augurar la recuperación del trono portugués por Felipe $\mathrm{V}$ como respuesta a la defección de Pedro II, que comenzó apoyando los intereses del duque de Anjou para aliarse a continuación con los imperiales.

La relación, sustentada por la creencia de que la Historia se repite y favorece a los justos, utiliza cinco episodios de la historia de Portugal con desenlaces desfavorables para los monarcas lusitanos como castigo a sus desmanes: el comportamiento inadecuado de un monarca, atentando de una u otra manera contra las leyes divinas, provoca una situación de desorden que se resuelve (el Cielo se presenta como factor de esa solución) con la ruptura de la línea sucesoria natural (ya no es el hijo quien sucede al padre en la Corona sino otro miembro de la estirpe) pasando a otra rama genealógica que, eso sí, sigue entroncada en el árbol sucesorio. No hay, pues, ruptura dinástica sino reforma en un asunto que deja al margen a la plebe y que se resuelve en la cúspide de la pirámide social por intervención de esa otra cúspide, ya universal, que es la Trinidad representada por un triángulo equilátero: la corona perderá el código genético del mal monarca pero mantendrá la pureza sanguí- 
nea que le es connatural. El rey que no respeta las leyes divinas no puede ser padre de rey, y la línea sucesoria se modifica ligeramente (sólo ligeramente): su prole queda apartada de la sucesión, aunque no por ello se rompe la línea sucesoria puesto que otro miembro de la progenie vendrá a sustituirlo. La naturaleza corrige sus mínimos errores, y siempre hay un miembro justo de la familia real para sustituir al infame que no respeta la Ley natural (la católica).

El relator, espigando en la historia portuguesa, encuentra algunos ejemplos que apuntalan su pronóstico (y que, como reconocerá al final de la relación, restan cualquier mérito a su augurio). Hace referencia, por ejemplo, al conflicto que se plantea cuando un apuntalamiento económico se sustenta en los enemigos de la cristiandad: cuando los judíos fueron expulsados de España, don Juan de Portugal les dio paso por su reino a cambio de grandes dádivas «pues de ofrecimientos de infieles no pueden resultar favorables los efectos [...] y Portugal passó a otra sucessión que no fue la del rey don Juan» (h.2r). El relator advierte una situación simétrica entre aquellos hechos de los últimos años del siglo XV y el conflicto hispanoluso de 1704, y previene a Pedro II respecto a los efectos que pueden suponer sus conciliábulos con las herejes monarquías inglesa y holandesa, beneficiosos quizá en aspectos económicos o políticos, pero gravemente perjudiciales para el catolicismo: «si dar passo a los judíos para huir de los católicos produxo aquellos efectos, ¿qué sería el dar passo a los hereges para conquistar a los christianos?» (h.2v)

La lectura de la Historia que hace el relator a lo largo de los cinco episodios augura un final feliz para Felipe $\mathrm{V}$ y, en consecuencia (y aunque el relator no lo explicite), para España. El impropio comportamiento del monarca portugués supondrá la ruptura de su línea sucesoria y será sustituido por un descendiente emparentado con los anteriores reyes portugueses: «en todos estos exemplares sucedió en Portugal, fuera de la línea del posseedor, un descendiente de aquellos antecessores reyes de Portugal» (h.2v). El desenlace es un ejemplo propagandístico en manos del relator que maneja con destreza los hilos del árbol genealógico lusitano para concluir que el sucesor natural «es nuestro glorioso y animoso Filipo [...] descendiente de don Dionisio el Fabricador, sexto rey de Portugal» $(\mathrm{h} 2 \mathrm{v})$. El autor de la relación reservaba para las últimas líneas la sorpresa y la traca final; hilvanando diversos acontecimientos de la historia portu- 
guesa surge el velado que, ex machina, se convierte en protagonista de la historia y de la Historia: Felipe V, a quien no se había mencionado, el joven aprendiz de rey, está llamado a ceñir sobre sus animosas sienes la corona española y la lusitana, tan añorada ésta por algunos de los hijos de quienes habían visto, sesenta años antes, la independencia de Portugal y con ella una de las señales de la decadencia de la monarquía hispana que ahora, en la persona de un «animoso» Borbón volvía a dar señales de aliento.

Aguilar Piñal catalogó dos ediciones del Pronóstico basándose en sendos ejemplares depositados en la Biblioteca de la Universidad de Sevilla:

a) Signatura 109-39 (8): sin datos tipográficos, consta de 2 hs. y presenta, respecto al ejemplar de la BUS, ciertas diferencias en el título título («Prognóstico», «para quien le lea» y «sucesso»). Aguilar Piñal [BAE-9 $\left.\mathrm{n}^{\circ} 4954\right]$ apunta como posible fecha de impresión el año 1703.

b) Signatura: 111-18 (26): titulado Prognóstico sacado de los reyes de Portugal, para que quien le lea o oyga haga el juizio que se inferirá de los sucessos passados para los presentes, y con colofón «En Sevilla, por Francisco de Leefdael, en la Vallestilla, año de 1704» [Aguilar Piñar, $B A E-9 \mathrm{n}^{\circ}$ 4954]. Cotejando una fotocopia de este ejemplar con la edición de la BUS hemos comprobado que ambos textos son prácticamente idénticos (salvo mínimas variantes ortográficas o achacables a la copia [p.ej: Rompiofe $v r$. Rompiole]). La diferencia más importante radica en la utilización de tipos de mayor tamaño en la edición de la Universidad de Sevilla que, aunque respeta la división de párrafos, modifica considerablemente la composición de las planas y duplica el número de hojas (de 2 a 4). El margen inferior del ejemplar sevillano está guillotinado, de manera que se ha mutilado tanto la signatura tipográfica como los reclamos. 


\section{ÍNDICES}

\section{Autores}

Asensio de Vicuña, Diego: 12.

Borbón, Luis de: 14.

Colbert, Jean Baptiste: 3 .

Español Profesor de Minerva, El: 13.

Luis XIV de Francia: 11.

Toulouse, Conde de: 14 .

Torcy, marqués de: 3.

\section{Impresores}

Barcelona:

- Francisco Guasch: 10.

Bruselas:

- E.H.Fritx: 4.

Cádiz:

- Cristóbal de Requena: 10.

Colonia:

- Pedro Nassau: 10.

Madrid:

- Antonio Bizarrón: A, B, C, D, E, F, G, H, 1, 3, 4, 7, 8, 9.

Sevilla:

- Francisco de Garay: 10.

- Francisco de Leefdael: 15.

- Herederos de Tomás López de Haro: 14.

Sin lugar:

- Sin impresor: I, 2, 5, 6, 11, 12, 13, $14,15$.

\section{Clasificación Temática \\ Militares:}

- Asaltos: 1, 8.

- Batallas navales: 12, 14.

- Batallas terrestres: 7, 9.
Política:

- Apología de Felipe V: 10, 15.

- Juramento real: 2 .

- Motivos de la guerra: 13.

- Relaciones internacionales: 3, 11.

- Viaje real. 4, 5.

Redención de cautivos: 6 .

\section{Fórmulas Editoriales}

Carta:

- Copia de carta: 3, 8, 12.

- Copia de la carta: 11.

Demostración:

- Clara demostración: 10.

Diario:

- Diario: 4.

Noticia:

- Noticias extraordinarias: 4.

- Noticias extraordinarias y singulares:

A, B, C, D, E, F, G.

- Noticia particular: 1.

- Noticias singulares y extraordinarias: $\mathrm{H}$.

- Noticias singulares y ordinarias: I.

Pronóstico:

- Pronóstico: 15.

Relación:

- Breve relación: 9.

- Puntual y sincera relación: 5.

- Relación verdadera y puntual: 6 .

- Relación: 2.

\section{Respuesta:}

- Breve respuesta: 10.

- Respuesta breve: 13.

«CUADERNOS DE ESTUDIOS GALLEGOS», Tomo XLIX, Fascículo 115, Santiago 2002. 


\section{BIBLIOGRAFÍA}

AGUILAR PIÑAL, BAE = AGUILAR PIÑAL, Francisco: Bibliografia de autores españoles del siglo XVIII, 10 vols., Madrid, CSIC, 1981-2002.

AGUILAR PIÑAL, PRENSA = AGUILAR PIÑAL, Francisco: La prensa española en el siglo XVIII. Diarios, revistas y pronósticos, Madrid, CSIC, 1978.

AGULLÓ, RS.1 = AGULLÓ Y COBO, Mercedes: Relaciones de sucesos I. Años 1477-1619, Madrid, CSIC, 1966.

AGULLÓ, RS.2 = AGULLÓ Y COBO, Mercedes: «Relaciones de sucesos (1620-1626)»: Homenaje a Don Agustín Millares Carló, vol. I, Gran Canaria, Universidad de Gran Canaria, 1975, pp. 349-380.

BACALLAR, Comentarios $=$ BACALLAR Y SANNA, Vicente, Marqués de San Felipe: Comentarios de la Guerra de España e Historia de su rey Felipe V el Animoso, Madrid, Ediciones Atlas, 1957.

$B N F=$ Bibliothèque Nationale de France. Catalogue BN-Opale plus [en línea]: http://catalogue2.bnf.fr (consulta realizada en abril de 2002).

BUSTAMANTE, $C B U-X V I I I=$ BUSTAMANTE Y URRUTIA, José María: Catálogos de la Biblioteca Universitaria [de Santiago de Compostela]. IV. Impresos del siglo XVIII, 3 vols., Santiago, El Eco Franciscano, 1954-1956.

CENTENARIO.GDM $=$ «III Centenario de la Gaceta de Madrid. 16611961», Suplemento al Boletín Oficial del Estado no 50 (1961), Madrid, 28 de febrero de 1961.

$C C F R=$ Catalogue Collectif de France, [en línea] http://www.ccfr.bnf.fr/, (consulta realizada en abril de 2002).

$C C P B=$ Catálogo Colectivo del Patrimonio Bibliográfico Español [en línea], http://www.mcu.es/ccpb/ccpb-esp.html, (consulta realizada en febrero de 2002).

«CUADERNOS DE ESTUDIOS GALLEGOS», Tomo XLIX, Fascículo 115, Santiago 2002. 
CUESTA, Romances = CUESTA DOMINGO, $\mathrm{M}^{\mathrm{a}}$ Pilar: «Guerra de Sucesión y cultura popular. Los romances como testimonio» en La Guerra de Sucesión en España y América: Actas X Jornadas Nacionales de Historia Militar (Sevilla, 13-17 de noviembre de 2000), Sevilla, Deimos, 2001, pp. 1085-1120.

DELGADO, Diccionario = DELGADO CASADO, Juan: Diccionario de impresores españoles (siglos XV-XVII), 2 vols. Madrid, Arco, 1996.

ETTINGHAUSEN, Prensa = ETTINGHAUSEN, Henry: «Prensa comparada: relaciones hispano-francesas en el siglo XVII» Estado actual de los estudios sobre el Siglo de oro. Actas del II Congreso Internacional de Hispanistas del Siglo de Oro, vol. I, Salamanca, Universidad de Salamanca, 1993, pp. 339-345.

GUTIÉRREZ, Ensayo = GUTIÉRREZ DEL CAÑO, Marcelino: «Ensayo de un Catálogo de impresores españoles desde la introducción de la imprenta hasta fines del siglo XVIII [2 ${ }^{\mathrm{a}}$ parte: Ca-Z]» Revista de Archivos, Bibliotecas y Museos 4-1900, pp.75-85, 267-272, 667-678 y 736-739.

HUARTE, Papeles $=$ HUARTE Y ECHENIQUE, Amalio: «Papeles festivos del reinado de Felipe V [V]», Revista de Archivos, Bibliotecas y Museos 35-1931, pp. 361-390.

HURTADO, Pronósticos = HURTADO TORRES, Antonio: «Pronósticos y Lunarios burlescos de los Siglos de Oro. Indice bibliográfico», Cuadernos Bibliográficos 40-1980, pp. 53-83.

KAMEN, Felipe $V=$ KAMEN, Henry: Felipe $V$. El rey que reinó dos veces, Madrid, Temas de Hoy, 2000.

KAMEN, GdS = KAMEN, Henry: La Guerra de Sucesión en España. 1700-1715, Barcelona, Grijalbo, 1974.

LEDDA, Informar = LEDDA, Giuseppina: «Informar, celebrar, elaborar ideológicamente. Sucesos y 'casos' en las relaciones de los siglos XVI 
y XVII», La fiesta. Actas del II Seminario de Relaciones de Sucesos (A Coruña, 13-15 de julio de 1998), Ferrol, Sociedad de Cultura Valle Inclán, 1999, pp. 201-212.

LÓPEZ-HUERTAS, Imp granadinos = LÓPEZ-HUERTAS PÉREZ, M ${ }^{\mathrm{a}}$ José: Bibliografia de impresos granadinos de los siglos XVII y XVIII, 3 vols., Granada, Universidad de Granada, 1997.

MORALEJO, Zaragozanas = MORALEJO ÁLVAREZ, María Remedios: «Dos publicaciones zaragozanas del siglo XVI desconocidas» en Homenaxe a Daría Vilariño, Santiago, Universidade de Santiago, 1993, pp. 487-492.

PALAU, $M L H=$ PALAU Y DULCET, Antonio: Manual del librero hispanoamericano, 28 vols., Barcelona, 1948-1977.

PENA, RS.Coruña = PENA SUEIRO, Nieves: Catálogo de Relacións de Sucesos (1500-1750) nas Bibliotecas da provincia da Coruña, Santiago, Xunta de Galicia, 1997.

PENA, Repertorio $=$ PENA SUEIRO, Nieves: Repertorio de Relaciones de sucesos españolas en prosa impresos en pliegos sueltos en la Biblioteca Geral Universitaria de Coimbra (siglos XVI-XVIII), Coimbra, Biblioteca Geral da Universidade (en prensa).

PÉREZ PICAZO, Publicística $=$ PÉREZ PICAZO, María Teresa: $L a$ publicística española en la Guerra de Sucesión, 2 vols., Madrid, CSIC, 1966.

RS.Felipe III = «Catálogo de relaciones sueltas, impresas durante el reinado de Felipe III» en Cabrera de Córdoba: Relaciones de las cosas sucedidas en la corte de España desde 1599 hasta 1614, Junta de Castilla y León, 1997, pp.1-10.

SANTOS, Contribución = SANTOS FERNÁNDEZ, Carlos: «Contribución al Catálogo de relaciones de sucesos en bibliotecas de la provincia de A Coruña» en Cuadernos de Estudios Gallegos 112-2000, pp. 401-439. 
SANTOS, Tormentas $=$ SANTOS FERNÁNDEZ, Carlos: «De tormentas y rosarios. La relación de un suceso acaecido en Santa Cristina de la Polvorosa (Zamora) en 1701, atribuible a fray Diego Carli», Studia Zamorensia 6-2002, pp. 107-147.

SEGURA, Pintura $=$ SEGURA SIMÓ, Ricardo: «La pintura y el grabado en la Guerra de Sucesión: La Batalla de Almansa» en La Guerra de Sucesión en España y América. Actas X Jornadas Nacionales de Historia Militar (Sevilla, 13-17 de noviembre de 2000), Sevilla, Deimos, 2001, pp. 953-986.

TORRIONE, Crónica = TORRIONE, Margarita: Crónica festiva de dos reinados en la Gaceta de Madrid, Bordeaux, CRIC, 1998.

UBILLA, Successión = UBILLA Y MEDINA, Antonio de: Successión de el rey don Phelipe V, nuestro señor, en la Corona de España. Diario de sus viages desde Versalles a Madrid, el que executó para su feliz casamiento. Jornada de Nápoles a Milán y a su Exército: successos de la campaña y su buelta a Madrid, Madrid, Juan García Infanzón, 1704. 